Studia nad Autorytaryzmem i Totalitaryzmem 43, nr 2

Wrocław 2021

https://doi.org/10.19195/2300-7249.43.2.2

JACEK BARTYZEL

ORCID: 0000-0003-1193-8515

Uniwersytet im. Mikołaja Kopernika w Toruniu

bartyzel@umk.pl

\title{
Catholic and monarchist nationalism in twentieth-century Portugal
}

\begin{abstract}
The subject of this article is Christian nationalism in twentieth-century Portugal in its two ideological and organizational crystallizations. The first is the Nationalist Party (Partido Nacionalista), operating in the late period of constitutional liberal monarchy, founded in 1903 on the basis of Catholic circles, whose initiator, leader, and main theoretician was Jacinto Cândido da Silva (1857-1926). The second is the metapolitical movement created after overthrowing the monarchy in 1914, aimed against the Republic, called Integralismo Lusitano. Its leader and main thinker was António Sardinha (1887-1925), and after his untimely death - Hipólito Raposo. Both organizations united nationalist doctrine with Catholic universalism, declaring subordination to the idea of national Christian ethics and the social doctrine of the Catholic Church. The difference between them, however, was that, although the party led by Cândido was founded, i.a., to save the monarchy, after its collapse, it doubted the sense of combining the defence of Catholicism against the militant secularism of the Republic with monarchism. Lusitanian integralists, on the other hand, saw the salvation of national tradition and Christian civilization in the restoration of monarchy - not liberal, but organic, traditionalist, anti-parliamentary, anti-liberal, and legitimistic. Eventually, the Nationalist Party gave rise to the Catholic-social movement from which an António Salazar's corporate New State (Estado Novo, 1889-1970) originated, while Lusitanian Integralism was the Portuguese quintessential reactionary counter-revolution, for which Salazarism was also too modernist.
\end{abstract}

Keywords: nationalism, Catholicism, monarchism, traditionalism, integralism, Christian civilization.

Twentieth-century Portuguese thinkers significantly contributed to the development of the doctrine of Christian, traditional, and monarchist nationalism. It is a relatively unknown fact and therefore we can safely say that Portugal still remains — not only in the literal, geographical sense — the peripheral "Balcony 
of Europe." And after all, during times of power and glory of the Lusitanian empire, the above-stated circumstance was transformed by the nation - which delivered such great discoverers as Bartolomeu Dias, Vasco da Gama, Pedro Álvarez Cabral, or Fernão de Magalhães - into the self-awareness of being the most westerly bastion of Christianity. The Portuguese conquest of the New World marked Portuguese spirituality with a stamp of missionary Catholicism and imperial messianism, since what was recognized as the paramount goal of this conquest was spreading Christianity (Cristandade).

This tradition of missionary Lusitanian monarchy was the source from which the contemporary manifestations of Portuguese nationalism ${ }^{1}$ derived inspirations, with the most outstanding example being the doctrine of the New State, ruled for many years in an authoritarian fashion by prime minister António de Oliveira Salazar (1889-1970). It is because nationalism was the primary and most important ideological self-identification criterion of the creator of Estado Novo, who at the thirtieth anniversary of the establishment of his government, when asked in an interview for the daily Le Figaro about the pillars of his political philosophy, answered with a succinct and straightforward declaration: "Je suis nationaliste..." [I am a nationalist $].^{2}$ Content-wise, Salazarism was reducible to the slogan: "everything for the Nation, nothing against the Nation," since Salazar started with the assumption that

the nation is living reality which we would strive to immortalize; $[\ldots]$ is an organic body composed of the individuals differentially endowed with abilities, competencies and characterized by different actions, that is of individuals quite unlike one another and hierarchized according to those differences. ${ }^{3}$

That is why the Constitution of the New State was founded upon "the solid, cautious, conciliatory nationalism which was supposed to assure the co-existence and proper functioning of all natural, traditional and progressive elements of the society." 4

Salazar's appearance and actions on the political arena were preceded by rather dramatic circumstances at the turn of the 19th and 20th centuries. Murdering the king and the successor to the throne in 1908, overthrowing the monarchy two years later, waging anti-Catholic terror by a democratic-masonic regime, unsuccessful monarchist uprisings, fractional battle in the Republican camp as well as ceaseless upheavals during which one president, bribery, economic-financial

${ }^{1}$ For more on Portuguese nationalism in general, see J. Ameal, Panorama do Nacionalismo português, Fernandes Júnior, Lisboa 1932; Q. Avelino de Jesus, Nacionalismo Português, Porto 1932; P.T. Pereira, Nacionalismo português, Coimbra 1967.

2 Le Figaro 9, 1958, no. 2-3, quoted after: J. Ploncard d'Assac, "Antonio de Oliveira Salazar ou un homme libre", [in:] idem, Doctrines du nationalisme, Vouillé 1978, p. 371.

3 [A. de] Oliveira Salazar, "Przedmowa", [in:] A. Ferro, Dyktator wspótczesnej Portugalii: Salazar, trans. E. Boyé, Warszawa 1936, p. XX.

4 [A. de] Oliveira Salazar, Rewolucja pokojowa, trans. Z. Grabski, Warszawa 1939, p. 58. 
scandals, galloping inflation. ${ }^{5}$ Apart from that, one prime minister ${ }^{6}$ was also murdered. At the time, two successive counter-revolutionary political schools existed which alluded - in "the first letter" of their "alphabet" - to the very notion of nationalism itself: 1. the Nationalist Party, operative in the last few years of monarchy, and 2. the meta-political movement labelled as Lusitanian Integralism, having emerged in response to the terror of militant democracy. Some activists of both above formations later gravitated towards Salazarism. However, the most prominent integralists assumed the attitude of standing in opposition to "Salazarchy." Still, it is not this dispute that shall constitute the subject matter of the present paper. Rather, the focal point thereof is the problem of monarchy in both variants of nationalism.

\section{Jacinto Cândido and the Nationalist Party}

It would not be an overstatement to say that the establishment of the first nationalism in Portugal is attributable to one man who also introduced the very word nationalism into Portuguese political discourse. ${ }^{7}$ Jacinto Cândido da Silva (1857-1926) was not only a thinker, but also a politician who had a rare virtue of resigning from his career once he realized that within the rigid structure of the

5 Sidónio Pais (1872-1918) from the Nationalist Republican Party, the president from 28 April 1918, murdered 14 December the very same year.

${ }^{6}$ António Granjo (1881-1921) from the Republican Liberal Party, a prime minister from 30 August 1921, murdered on 19 October of the very same year. When it comes to historical science, this event is referred to as Noite Sangrenta [Bloody night], during which Carbonari units abducted and murdered the prime minister, five ministers, and a few dozen co-operators of theirs; moreover, the head of the said military units - Manuel Coelho - was appointed by the president the head of the government, which is historically known as "the government of murderers." However, he was forced to step down after seventeen days under the pressure exerted by BritishSpanish squadron, which entered the port in Lisbon.

7 The above claim is made by: the author of the foreword to Cândido's Pamiętniki [Diaries] - José Lopes Dias (see J. Cândido da Silva, Memórias íntimas para o Meu Filho (1898-1925), ed. J.L. Dias, Castelo Branco 1963, p. 17) as well as J. Ploncard d'Assac, "L'ideé nationaliste au Portugal", [in:] idem, Doctrines du nationalisme, pp. 315-324, which is in turn confirmed by the two prominent experts on the former's thought - Vítor Neto and Nuno Olaio. It is certain that Cândido used the very word in question - while defining it as "philosophical-political corpus of a social doctrine concerning governance" and simultaneously pointing as its goal to "the defense of Catholic truths, that is of the foundation of civilization," whereas what he perceived as a means was its being constitutive of a political party — as early as 1892 in As medidas de salvação pública, nas sessões da Câmara dos Deputados de 13 e 17 de Janeiro de 1892, Imprensa Nacional, Lisboa 1892. The thought and actions and Cândido were subject to scholarly scrutiny only in the recent decades — see A. Carvalho da Silva, O Partido Nacionalista no contexto do Nacionalismo Católico (1901-1910), Lisboa 1996; V. Neto, "O nacionalismo católico em Jacinto Cândido", Revista de História das Ideias 22, 2001, pp. 395-417; N. Olaio, "Jacinto Cândido da Silva (1857-1926): o nacionalismo católico através das memórias de um dos seus fundadores”, Lusitania sacra 16, 2004, series 2a, pp. 147-178. 
liberal monarchy establishment, it is impossible to do politics able to bring about the restoration of Portugal. At this point, one should briefly recall that, since the military solution of the War of Two Brothers (Guerra dos Dois Irmãos) in 1834 in favour of liberals, Portugal was a rickety constitutional monarchy under the reign of unpopular rulers descending from liberal Peter IV (Dom Pedro), who abdicated to be replaced by his daughter Dona Maria II. Then, as a consequence of her marriage with the prince of the house of Saxe-Coburg and Gotha, since the enthronement of their son, Peter V (1853), the lineage of the House of Braganza was transmitted only on the distaff side. The defenders of the king-traditionalist Miguel I (Dom Miguel) - centred around the Legitimist Party (Partido Legitimista), colloquially referred to as miguelistas (miguelists), ${ }^{8}$ who were also representative of Catholic ultramontanism - got virtually removed from political life.

The first period of the constitutional reign was marked with constant military and civil upheavals as well as battles among different fractions of the liberal camp, which were all without exception related to masonry. Only in 1851, the prominent leader of the conservative wing, Marshal João duke (duque) of Saldanha (1790-1876), after having conducted another putsch, managed to impose on all the fractions an informal consensus involving establishing the condition that conservative liberals - henceforth operating under the name of the Regenerator Party (Partido Regenerador) - and progressive liberals - originally called the Historic Party (Partido Histórico), and from 1876 the Progressive Party (Partido Progressista) - shall govern alternately. This system, also referred to as bipartisan "rotativism" (rotativismo), was theoretically modelled after the British paradigm of parliamentarism, but practically implemented through the interventions of so-called caciques. These are local notables being dependent on heads of political parties, with the latter paying the former for winning - by dint of the promises or threats made - voters' votes, which allowed settling a desired result prior to formal elections, which were preceded by the king's appointing a new cabinet council. In other words, it was not the party who won the elections that came into power, but rather it was the party who already came into power that "won" the elections. After all, the mechanism led to heavy political bribery and neither prevented the development of anti-system movements (republican, anarchist, or socialist ones), nor did it preclude the ongoing degradation of the country on the international arena. ${ }^{9}$ Yet, at the very least, it stabilized the political life of a "legal country" until the end of the 19th century.

8 On the history of miguelism, see M.A. Lousada, "Nacionalismo e Contrarevolução em Portugal. O episódio Miguelista (1823-1834)", Luso-Brazilian Review 29, 1992, no. 1, pp. 63-70; eadem, "El miguelismo o la contrarrevolución en Portugal", [in:] Identidad y nacionalismo en la España contamporánea; el Carlismo, 1833-1875, ed. S.G. Payne, Madrid 1996, pp. 181-194; A. Barreiros Malheiro da Silva, Miguelismo. Ideologia e mito, Minerva,; M.T. Mónica, Errâncias Miguelistas (1834-43), Lisboa 1997.

${ }^{9}$ Its high point was a brutal ultimatum of 1890, supported by the anchoring of the squadron of the fleet in close proximity to the Tagus estuary, issued on the part of a "traditional ally" of Portugal, 
Coming from an aristocratic family in Azores, Cândido had an easier "start in life" both at the level of local and national politics. Since 1887, he was a member of the parliament five times, being a representative of the Regenerator Party, and from November 1895 until February 1897, he was a minister of navy and overseas territories in the cabinet of Ernesto Hintze Ribeiro (1849-1907). It is precisely the collapse of this government and a progressivist coming into power that became catalysts for Cândido's decision to break with the entire liberal political class and engage in bringing about new political quality - nationalism founded upon social teachings of the Pope Leo XIII in the then recently (1891) published encyclical Rerum novarum. This initiatory idea is audible in the tone of a series of speeches made by Cândido, bearing the telling title Vida Velha e Vida Nova [Old Life and New Life]. Its leitmotif is calling for overcoming particracy, rotativism, caciquism as a preliminary as well as necessary condition for restoring Portuguese political life and recovering the faded splendor of old monarchy through grounding it in social Catholicism. ${ }^{10}$ However, the catalogue listing these major defects of the political system (under which Cândido also subsumed personalism, ${ }^{11}$ oligarchy, and centralism) is paralleled by equally grave vices of the Portuguese society: indifference, absenteeism, scepticism, and the failure to comprehend civil duties. ${ }^{12}$ The first stage of establishing a new political camp was seizing the daily Correio Nacional [National Courier] in 1989, which had been founded five years before and recognized as a semi-official body of the Portuguese Episcopate. The second stage involved founding the association of the National Centre (Centro Nacional) in 15 June 1901, the ruling council which comprised Cândido and Count (conde) de Bertiandos ${ }^{13}$ (1851-1929) and Professor Gonçalo Xavier de Almeida Garrett (1841-1925). On 29 December 1900, king Carlos I (Dom Carlos) appointed Cândido a peer of the Kingdom, which allowed him to render the Chamber of Peers a tribune for his own ideas.

The third and at the same time decisive stage was the transformation of the circles (circulos) of the Centre into the Nationalist Party (Partido Nacionalista) during the founding congress in Porto between 1-3 June 1903 at the residence of the Catholic Action. Its co-founders were (apart from Cândido and duke de

that is by the Great Britain, which demanded the Portuguese's retreat from the territories of the South Africa being under dispute.

10 See J. Cândido, Vida Velha e Vida Nova. Discurso proferido na sessão de 18 de Abril de 1902, Lisboa 1902.

11 What is meant by personalism in the author's political framework is not a philosophicalanthropological standpoint, but rather the personalization of politics, which involves the unreflective attachment not to the ideas and principles of the movement's doctrine, but rather to parties' leaders and getting subjugated to their personal wills.

12 See J. Cândido, A Doutrina Nacionalista, Porto 1909, pp. 27-34; idem, Memórias..., pp. 54, 121.

13 Strictly speaking, Gonçalo Pereira da Silva de Sousa e Meneses, third Count de Bertiandos. 
Bertiandos): doyen of Catholic politics ${ }^{14}$ - Count de Samodães ${ }^{15}$ (18281918); prominent Catholic journalist and publicist, Lieutenant Colonel Engineer Fernando de Sousa (1855-1942); historian of the Church Manuel Abúndio da Silva (1874-1914), as well as Reverend António Manuel da Silva Abreu, José Pulido Garcia, Jerónimo Pimentel, and others. Cândido was appointed the head of the party's Central Commission. In the programme adopted during the congress, the Nationalist Party emphasized the three following points: 1. protecting freedom and the rights of Church; 2. applying the principles of Christian economics, especially to industrial and agricultural issues; 3 . protecting the supreme interests of the state: moralizing politics and a political system, coupled with paying special attention to the colonial issue. ${ }^{16}$ During the second congress of the Nationalist Party (which gathered 400 participants) in the palace of Viscount Carreira in Viana do Castelo, 2-4 July 1905, the words "God, Homeland, Liberty" were assumed as the party motto. In total, the Nationalist Party held five congresses: ${ }^{17}$ the third in Braga (28-30 October 1907), fourth in Viseu (29 September-1 October 1908), and fifth again in Porto (14-16 November 1909). The sixth congress, scheduled for 1911 in the city of Guarda, fell through due to the October Revolution, which swept off monarchist regimes.

In the political doctrine elaborated by Jacinto Cândido, one should first and foremost take heed of the - oftentimes called into question, but here treated as natural or even spontaneous - symbiosis of nationalism and Catholicism. Their mutual, in the author's view, inclination towards one another was already articulated in the manifesto of the association, in which Cândido announced that "the National Centre, the motto of which is 'Religion and Homeland', shall promote the rights and liberties of Church, apply the principles of social economics and protect the supreme interests of the state, which - by its very nature - must be put above whatever disputes or inter-party divergent views." 18 Several months later, however, he added: "it is an erroneous contention that the National Centre deals exclusively with religious issues or with Christian social economics. Rather, it defends all the national interests." 19 Finally then, under the influence of the sociological thought of French social Catholic, nationalist, and passionate anti-Semite - Édouard Drumont (1844-1917), Cándido came to the conclusion that the expression best fitting the intent of combining the protection of religious, nation$\mathrm{al}$, and social interests is precisely nationalism itself, the consequence of which

14 See E.C. Cordeiro Gonçalves, Católicos e Política (1890-1910) - O Pensamento e Acção do Conde de Samodães, Maia 2004.

15 Strictly speaking, Francisco de Azeredo Teixeira de Aguilar, second Count de Samodães.

16 See Programa Nacionalista, Tipografia Peninsular de Monteiro \& Gonçalves, Porto 1903.

17 See M. Casa Nova Martins, "Congressos do Partido Nacionalista”, Alameda digital 1, 2006, no. 2, http://www.alamedadigital.com.pt/n2/congresso_nacion.php.

18 Correio Nacional, 18.07.1901, quoted after: J. Ploncard d'Assac, Doctrines du nationalisme, p. 318 .

19 Correio Nacional, 1.10.1901; quoted after: Ibidem, p. 318. 
was the adoption of the party name. After all, it is only nationalism that can "purify, temper and strengthen national life, and in the light and under the influence of Christian principles - it can improve our civilization." 20

However, was this disambiguation not tantamount to disassociating oneself from "Christian social economics" and relaxing the connection with Church teachings in general? Quite the contrary - it was a proof of adjusting to then recently (in the encyclical Graves de communi dating back to 18 January 1901) issued Pope Leo XIII's recommendations, rather categorical in their tone. The recommendation was that the notion of "Christian democracy" should not be given any political significance, while reserving it to social acts of charity; or, in other words, to demophilia. Therefore, desiring to conduct political actions proper as one of the pillars of their programme, which would still embrace social reforms, Catholics (Portuguese patriots) had to find a new strictly political formula for their actions, which turned out to be nationalism itself. As Cândido explained, modifying the formula does not imply the reversal of the value hierarchy (in which religion occupies the highest rank) because nationalism is not an a priori or stand-alone ideology, but rather it is subservient to the nation shaped according to a religious tradition:

[Nationalism] is a natural and spontaneous product of the movement of public opinion, while being determined by a coincidence of various circumstances under a certain historical situation; and it did not derive from any other sources than a simple element of equilibrium of the political life of the Nation. As a consequence of its evolution, this very movement incurs a duty to preserve religious principles and key public interests, thus assuming a form of an autonomous political party. ${ }^{21}$

It should also be noted that while assuming nationalism as an ultimate expression of his ideological position, Cândido immediately introduced into his political discourse the distinction between a "conditional nationalist" (nacionalista condicional), that is one abiding by Catholic principles and the spirit of social actions of Church, and a "pure nationalist" (nacionalista puro), which is one who frees themselves of any ties with Catholic nationalism. As a matter of course, he repudiated the latter position. ${ }^{22}$ Catholic nationalism, on the other hand, is: "1. the opposite of the personalization of politics; 2 . the opposite of factional spirit; 3. zealous patriotism; 4. a critique of modern vices and mistakes; 5 . audacious reformer; 6 . fearless evangelist; 7. defender of Catholicism." 23 The dynamism of nationalism puts a quest for truth above striving for power; certainly, it does not disown the latter, but the main goal it sets for itself is "the triumph of Truth; and hence, a triumph of Good." 24

20 J. Cândido da Silva, Memórias..., p. 115.

21 Correio Nacional, 18.06.1903, quoted after: J. Ploncard d'Assac, Doctrines du nationalisme, p. 322 .

22 Correio Nacional, 15.02.1902, quoted after: N. Olaio, op. cit., p. 156.

23 J. Cândido da Silva, Memórias..., p. 113.

24 Ibidem, p. 120. 
Sharpening the hierarchy of problems, one should place in the center of our attention the political, social and the religious. Undoubtedly, the fundamental issue is religion. It constitutes a foundation of morality. And morality in turn is a foundation of the social issue in its essence. The latter is nowadays a very pressing issue indeed. [...]. There is no left, no right that could remove it or attenuate it. Nor are there any well-known circumstances able to mitigate it. ${ }^{25}$

In the article "The Holy See and the Nation," published in A Palavra [Word], Cândido stressed that the central position occupied by religion in the nationalist political thought stems from the assumption that religion constitutes an ontological justification of the state and society.

At times, between politics and religion there occur lamentable tensions which are always evil because they follow from the assumption that a religious principle may be a supplementary and subservient to political institutions instead of being a main factor for the Nation and a target uniting all the forces of national public life. [...] And this unfortunate mistake is unbearable. $[\ldots]$ Is the one who puts his political beliefs above his religious faith a Catholic worthy of its name? ${ }^{26}$.

In the same text, we can encounter the political aspect of the distinction foefriend: "The fundamental dividing line is this: on the one hand, masonry and socialism - while on the other: Church and conservatives of the social order." 27 Catholic nationalism is an advocate of order and a preserver of laws, "a genuine defender of order, which they [Masons-Jacobins] want to destroy and their only opponent who cannot be corrupted, controlled and subjugated." 28 It is only in connection with order - the transcendent one - that the notion of progress may be endowed with a clear and worthy meaning: "There is no progress without order, there is no order without morality, there is no morality without religion and hence, there is no progress without religion." ${ }^{29}$ In Cândido's view, progress is justified as a means to approximate social harmony; it is a "way of specifying and solidifying order, which is a warranty of social stability and liberty." 30 Order as conceived of by Catholics also preserves the harmony between individual liberty and common good - this, however, requires setting some intransgressible boundaries of freedom, with its exercise having to be "fair and just" in each case. ${ }^{31}$

And so, despite the fact that the party assumed the self-identifying label of $n a-$ tionalism, what was of primary importance in the programme of the party remained

25 Ibidem, pp. 355-356.

26 J. Cândido da Silva, "A Santa Sé e a Naçao", A Palavra 21, 1904, no. 285, quoted after: N. Olaio, op. cit., p. 148.

27 Ibidem.

28 J. Cândido da Silva, Memórias..., p. 114.

29 Ibidem, p. 317.

30 J. Cândido da Silva, As medidas de salvação pública, nas sessões da Câmara dos Deputados de 13 e 17 de Janeiro de 1892, Lisboa 1892, quoted after: N. Olaio, op. cit., p. 166.

31 J. Cândido da Silva, Resposta a El-Rei, discurso nas sessões de 23, 27 e 28 de Novembro de 1906, Lisboa 1907, pp. 26-27. 
— as stressed by Abúndio da Silva — the affirmation of Catholicism. ${ }^{32}$ Hipólito Raposo, a prominent representative of the "second wave" of Portuguese nationalism - that is, Lusitanian Integralism - approvingly stated that the Nationalist Party "was unconditionally dedicated to the principles of Catholicism and it underlined its respect to the harmony between the state and Church." 33

In the parliamentary elections (the first one in which the party in question could participate) of 1904, the Nationalist Party had only one deputy in the parliament. It was a lawyer and a local government activist from Braga António Peixoto Correia (1868-1910). In the elections dating back to February 1905, two nationalists entered the parliament: Canon António Homem de Gouveia (1869-1961) from Funchal in Madeira, and yet again Peixoto Correia. "Rotativism" still successfully ensured the marginalization of small parties; hence, at the second congress of the Nationalist Party, they decided on a tactical electoral alliance of "liberal concentration" with Hintze Ribeiro's Regenerationists. This allowed them to have six deputies in 1906. Apart from the two previous ones, the remaining four were: Fernando de Sousa, general de Lacerda, Manuel Pestana da Silva, and José Joaquim de Morais Miranda. However, in the elections of 1907, only one nationalist (Canon Gouveia) remained in the house. In the elections dating back to April 1908, the Nationalist Party put up 32 candidates, but then again, only one came through - lawyer, poet, playwright, and journalist Alberto Pinheiro Torres (1874-1962) from Braga. In the last elections, dating back to August 1910, right before monarchy was overthrown, nationalists appeared in the integrated block of all the parties protecting the then existent regime under the name of Monarchist Electoral Coalition (Coligação Monárquica Eleitoral). It was exactly then that Cândido lost his faith in saving the monarchy, given a king so weak and separated from the nation ${ }^{34}$ as Emanuel II (Dom Manuel). In the diaries he wrote later, Cândido expressed regrets concerning his predecessor, Carlos I: "Never has any nationalist element entered any royal governance; and neither has the Nationalist Party exerted any influence upon the direction of the said governance $[\ldots]$; fearing liberals and Jacobins, neither the king nor queen supported me in my efforts — with the efforts being, after all, legal in their nature - to protect the institution [of monarchy]." 35

Starting to doubt the validity of monarchy certainly did not imply approving the Republic, which at that time was a revolutionary "state of the civil war." In his

32 See M. Abúndio da Silva, Nacionalismo e Acção Católica, Porto 1909, p. 59.

33 H. Raposo, Dois Nacionalismos: l'Action Française e o Integralismo Lusitano, Lisboa 1929, p. 22.

34 The burden of a crown fell unexpectedly on an eighteen-year-old feeble Dom Manuel, at the moment (1 February 1908) his elder brother was assassinated. Dom Luís Felipe died from blood loss after twenty minutes. A short (concluded with a republican upheaval of 5 October 1910) episode of the reign of Emanuel II was recorded in history as the period of "Monarchy of surrender."

35 J. Cândido da Silva, Memórias..., p. 152. 
Private diaries for my son, Cândido recorded what follows: "As you can see now, the all famous republic, this outstanding regime of liberty, equality and brotherhood is nothing more than tyranny executed by the frightening oligarchy." 36 Since it is indeed the case that revolutions target the Catholic religion and its organizations with the most extreme fury and vehemence and it is the main aim of Catholic nationalism - as Cândido concluded - to defend the said institutions, nationalist should no longer defend overthrown and useless monarchy, but should rather become the "extreme right wing of the Republican Party." ${ }^{37}$ Henceforth, the central issue of Catholic nationalism was to be exclusively protecting the nation: "the nation for the nation - and through the nation - will be its motto." 38 Although he thus advised his proponents, he could not think of any room for himself under the newly emergent circumstances. Hence, he decided to resign from politics altogether.

My spirits are sinking because I am in doubt while being afraid of the future although I did not lose all the hope. However, all my share in public life is now gone. My position as to the participation in this life after the revolution I expressed in the following concise formula: I do not join, not conspire, not warn and I step back [orig. não adiro, não conspiro, acato e retiro - J.B.]. ${ }^{39}$

After Cândido's retreat into the shadows, Pinheiro Torres ("anointed" by Cândido himself) summoned the gathering of the National Commission on 16 December 1900 in Porto and put forward the suggestion that the party should maintain its fundamental programme: the defence of religion and homeland. ${ }^{40} \mathrm{In}$ line with the above suggestion, nationalists set up a new Central Commission comprising: Pinheiro Torres, former Miguelist from Legitimist Party - lawyer Domingos Pinto Coelho (1855-1944) from the Nationalist Centre in Lisbon, and monsignor Joaquim Domingos Mariz from the Nationalist Centre in Braga. The Commission decided to focus its operations on rebuilding local structures and on defending "the minimum programme," that is one "encompassing rights and vital liberties of Church and legitimate laborers" wage claims." 41 The republican regime, however, precluded the re-establishment of the party's operations and the repressions also fell on Cândido, who - although he had resigned from political activity - at that time was sentenced to exile. He decided to stay in France. In 1915, he was allowed to come back to his homeland on the condition that he should settle in a small town: he picked Penamacor, bordering Spain. Cândido engaged in establishing the Portuguese Catholic Centre (Centro Católico Português) ${ }^{42}$ — founded

36 Ibidem, p. 136.

${ }^{37}$ Ibidem, pp. 55-56.

38 Ibidem, p. 55.

39 Ibidem, p. 54. To fully appreciate his attitude, it is worthwhile to mention that he always considered himself "a passionate legalist" — see J. Cândido da Silva, Resposta a El-Rei..., pp. 23-24.

40 See $O$ Grito do Povo 12, 1910, no. 602, quoted after: N. Olaio, op. cit., p. 161.

41 Ibidem.

42 The person who also joined the policy pursued by CCP was a professor of economics at Coimbra - Salazar, who back in 1921 was elected as CCP's representative to the parliament, but who after only three days stepped down, disgusted with democratic habits. 
in 8 August 1915, after the appeal issued by the Episcopate - ran by his former cooperators, Pinheiro Torres, Fernando de Sousa, and Diogo Pacheco de Amorim (1888-1976). It was to CCP that Cândido attributed realising the main goal of Catholic nationalism, that is the defence of religion and Catholic civilization: "Yesterday, nationalism constituted a political party with a full programme of governance and administration. Today, the Catholic Centre organized itself as an instrument for protecting religion from personal and partisan assaults [...], from triumphant and oppressive revolution, [...] from tyrannical government." ${ }^{43}$ However, it was already in 1918 that he assessed the Centre more moderately not as a continuation, but a successor of nationalism.

The Catholic Centre is more or less a new stage of nationalism, which is my doctrine. Today, as yesterday, I believe that revolution will fail to achieve anything stable with respect to a social structure. What is at stake these days is not monarchy or republic but rather - moral foundations of the civilization. ${ }^{44}$

As can be seen, Cândido dissociated himself more and more from the monarchists plotting (rather poorly, it must be noted) for the sake of the restoration; on the other hand, he supported and even admired president Sidónio Pais, who restored basic liberties to the Church and who set free political prisoners as well as began establishing the presidential system, hitherto unknown in Europe. The restoration of monarchy, in his view, would be a mere half-measure because it would amount to the personal restoration as an end itself, whereas what was of utmost importance were the interests of the nation, not of the monarchist faction: "the restoration desired by righteous people is not the restoration of monarchy but of what is of national character." 45 Catholics should emancipate themselves from monarchists; otherwise they would fall victim to the latter's impatience, since they are after all a "voracious horde driven by interests, vanity, ambition, regrets and filled with the sectarian spirit; vicious minions of the king, with the latter putting unlimited trust in them, and with the former also being proud and arrogant towards the country they did not like." ${ }^{\prime 6}$ In 1918, Cândido rejected the invitation issued by the official viceroy of Dom Manuel (at that time remaining in exile in London), colonel Aires de Ornelas (1866-1930), with the aim of meeting at the headquarters of Monarchist Youth. Cândido explained that he always adhered to monarchic principles, but conceded that in the current situation, these principles were of no use to the national issue ${ }^{47} \mathrm{He}$ assumed an even more radical tone in his letter (never to be sent, as transpired) to cardinal-patriarch of Lisbon, Dom António Mendes Bello (1842-1929):

\footnotetext{
43 J. Cândido da Silva, Memórias..., p. 186.

44 Ibidem, p. 285.

45 Ibidem, p. 273.

46 Ibidem, p. 262.

47 Ibidem, p. 255.
} 
It is not a monarchist banner, but a Christian banner that must be the one which will unite all the defenders of the Order. The Monarchist Party is a grave mistake, being tantamount to almost a social or patriotic crime. All conservative political forces should converge on the [Catholic] Centre without raising regime-related issues. ${ }^{48}$

Cândido definitively broke his connection with monarchists during the eighteen-day uprising in Porto (19 January-13 February 1919), during which the Royal Commission with Colonel Henrique de Paiva Couceiro (1861-1944) proclaimed the so-called Monarchy of the North. In this hastily improvised revolt, apart from a factional spirit, Cândido saw that the monarchist issue was deemed more important than the question of homeland, and it was precisely the reason he condemned it.

A lack of patriotism, bad incidents of personalism and partisanism, neglecting the needs of the country, utter stupidity, failure of the revolt from the political point of view; all this, coupled with a repugnant and readily noticeable divergence between declarations — rather formal and solemn - and facts, with the latter contradicting the former; and finally, the genesis of the movement, which instills in me the fear of the future of this unfortunate country - all these factors urged me to refrain from participating in this unfortunate civil war, ignited by this ill-fated Monarchist Party. ${ }^{49}$

However, Cândido became disappointed with the Catholic Centre, too, having noticed the paradox that Catholics always operate within the constraints of legal and moral nature, whereas revolutionists do not bother with such "trivialities. ${ }^{\circ 0} \mathrm{He}$ rejected the proposal for being a CCP candidate for the senate. Once again, and this time definitely, he resigned from politics. He died in Lisbon on 26 February 1926. The literary corpus he left consisted of two memoirs: the short Autobiography, encompassing the years of his youth, ${ }^{51}$ and the comprehensive Private diaries for my son, published in 1964 and consisting of 87 chapters. The latter actually tackled the issues related to his political activities dating back to the nationalist period as well as to his waning years.

\section{António Sardinha and Lusitanian Integralism}

What proved to be a more persistent ideological-political phenomenon of Portuguese counter-revolutionary right than the Nationalist Party was a multigenerational movement brimming with outstanding thinkers, labelled as Lusitanian Integralism (Integralismo Lusitano). The first constituent of this phrase alluded to the doctrine of nationalisme intégral (integral nationalism), known to the movement's founding fathers. It originated from French thinker Charles Maurras (1868-1952), but the latter constituent of the phrase made a reference to the archaic expression

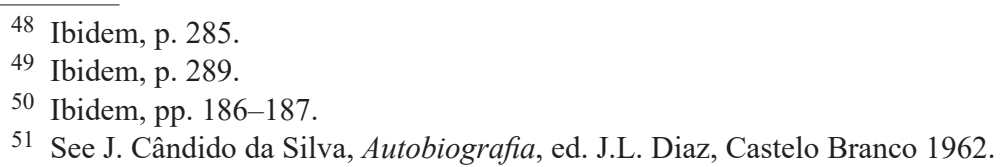


denoting the Celtic ancestors of Portuguese people, that is the Lusitanians, who were believed - according to national mythology - to have descended from Lusitanus, son of Tubal and Noah's descendant. This movement, centred around the magazine A Nação Portuguesa [The Portuguese Nation], ${ }^{52}$ issued from August 1913, formally founded in April 1914, legalized in April 1915, and delegalized for complicity in the monarchist uprising in 1919. It reinstated three years later, only to be suspended after the military revolt of 1926 and ultimately (self)dissolved after the Constitution of the New State was assumed, dating back to July 1933, after swearing an allegiance to the King de iure - Edward II (Dom Duarte Nuno). Actually, it existed as an informal metapolitical environment through the entire epoch of the New State, ${ }^{53}$ and it is operative to the present day in vestigial and ectypal forms. ${ }^{54}$

52 It was preceded with the issuance of - in exile in Ghent (which was the place of residence for the Portuguese students of the Catholic University of Leuven) - the almanac Alma Portuguesa [The Portuguese Soul] with the subtitle "Órgão do Integralismo Lusitano," which was edited by Domingos de Gusmão Araújo (1889-1959). However, there were only two issues thereof released: the first in May 1913, and the other in August of the same year. The initiator and spiritual leader of this youth was Benedictine monk fully aware of the legacy of Action française, Reverend Amadeu de Vasconcelos OSB (1879-1952), publishing (in Paris between August 1913 and the beginning of 1916) the series called Os Meus Cadernos under the pseudonym "Mariotte." The first series of A Nação Portuguesa, issued till 1916 under the supervision of A. Monsaraz, bore the subtitle "Revista de Filosofia Política," whereas the second series, edited from July 1922 till the end of 1923 by A. Sardinha, bore the subtitle "Revista de Cultura Nacionalista." The third series, between 1924 and 1926, was first edited by Sardinha, and after his death - by M. Múrias. The editorial secretary of the fourth series (1926-1928) was M. Caetano. From 12 February 1917, integralists also started to issue the daily A Monarquia, edited by A. Monsaraz and J. do Amaral, suspended by the then authorities in January 1919 and resumed 18 August of this year with the editor-in-chief now being $\mathrm{H}$. Raposo, only to be again — and this time ultimately — prohibited on 6 May 1922. There were also two more illegally released issues: 10 December 1922 and 5 April 1923, as well as the special issue after Sardinha's death, dated 10 February 1925.

53 The New State was joined rather by representatives of the second and third generations of integralists, headed by Marcello Caetano and João Ameal as well as (though not immediately, but only after suppressing the national-syndicalist movement putsch with which they were associated) by Manuel Múrias, Dutra Faria, Barradas de Oliveira, and Cabral de Moncada. When it comes to the first generation - the only ones were João do Amaral, Fernando Campos, Caetano Beirão, Alfredo Pimenta, and José Cabral. Beirão and Pimenta, after all, remained outside the movement from 1921 onwards because they did not accept its fusion (taking place one year earlier) with the Legitimist Party. On the difficult relationship between integralism and Salazarism, see J. de Almeida, Nacionalismo e Estado Novo, Lisboa 1932; M. Múrias, Tres Gerações e o seu destino, Lisboa 1941; A. Cordeiro Lopes, O pensamento e a acção de João Ameal - Um percurso antimoderno, entre o Integralismo e o Salazarizmo (1917-1934), Lisboa 1995. On those "dissidents" of integralism (Rolão Preto, Alberta de Monsaraz) fascinated with Italian fascism, who in 1932 founded national-syndicalist movement (Movimento Nacional-Sindicalista) and made an effort to forcefully overthrow Salazar's regime, see J. Medina, Salazar e os Fascistos. Salazarismo e Nacional-Sindicalismo a história dum conflicto 1932-1935, Lisboa 1978; A. Wielomski, "Faszyści portugalscy wobec dyktatury Antonio de Oliveiry Salazara", [in:] idem, Faszyzmy tacińskie. Sen o rewolucji innej niż w Rosji i w Niemczech, Warszawa [2011], pp. 219-237.

54 A basic secondary literature of Lusitanian Integralism comprises the following: F. da Vide, O Pensamento Integralista. Seus fundamentos histórico-scientificos, determinação e oportunidade do

Studia nad Autorytaryzmem i Totalitaryzmem 43, nr 2, 2021

(C) for this edition by CNS 
In the subject-matter literature, there are four generations (geraçãos) of integralists distinguished. A charismatic, yet untimely deceased (at the very young age of 37) leader and theoretician of integralism was philosopher and poet António Sardinha (1887-1925). Other prominent representatives of the first generation (Primeira Geração) of integralists were, among others: the author of the movement's name, Luís de Almeida Braga (1886-1970); successor of Sardinha in the sense of being a leader of the movement, Hipólito Raposo (1885-1953); one of the biggest landowners in Portugal, Pequito Rebelo (1892-1983); journalist João do Amaral (1893-1981); lawyer Adriano Xavier Cordeiro (1880-1919); historian of Portuguese counter-revolutionary thought Fernando Campos (1891-1958); writer and historian Caetano Beirão (1892-1968); historian, philosopher, and poet Alfredo Pimenta (1882-1950); lawyer Rui Enes Ulrich (1883-1966); Afonso Lucas (1893-1946); and two later national-syndicalist "dissidents" - Francisco Rolão Preto (1893-1977) and Alberto de Monsaraz (1889-1959). Sardinha, Cordeiro, Raposo, Amaral, Pequito Rebelo, Monsaraz, Almeida Braga, and (after Cordeiro's death) Professor Ulrich comprised the first Central Junta of Integralism. ${ }^{55}$

The second generation (Segunda Geração) of integralists, ones who launched their operations after 1922, included: the most exquisite twentieth-century philosopher of law in Portugal Luís Cabral de Moncada (1888-1974); historian and publicist Manuel Múrias (1900-1960); philosopher, writer, and historian João Ameal (1902-1982); the first historian of integralism Leão Ramos Ascenção (1903-1980); and expert in administrative law and the successor of Salazar at the position of the prime minister Marcello Caetano (1906-1980), among others.

The figures regarded as the third generation (Terceira Geração) of integralism are ones who entered public life after the military revolt of 1926 and during the period of the formation of the New State, in the 1930s and 1940s centred around the cultural magazine Gil Vicente, edited by Manuel Alves de Oliveira

seu objectivo social e político, Lisboa 1923; F. Campos, A Genealogia do pensamento nacionalista, Lisboa 1931; L. de Almeida Braga, Posição de António Sardinha, Lisboa 1943; L. Ramos Ascensão, O Integralismo Lusitano, Porto 1943; J. Ploncard d'Assac, “Antonio Sardinha et l'Intégralisme Lusitanien", [in:] idem, Doctrines du nationalisme, pp. 325-338; R. Proença, Acerca do Integralismo Lusitano, Lisboa 1964; C. Ferrão, O Integralismo e a República. Autópsia de Um Mito, Lisboa 1964-1965; H. Barrilaro Ruas, "O Integralismo como doutrina política", [in:] idem, A Liberdade e o Rei, Lisboa 1971, pp. 191-206; M. Nazaré Barros, L. Bernardo, J.A. Cunha, A Filosofia política no Integralismo Lusitano, Lisboa 1987; P. Archer de Carvalho, Nação e Nacionalismo - Mitemas do Integralismo Lusitano, Coimbra 1993; M. Saraiva, "Integralismo Lusitano e sua Actualidade", [in:] idem, Frontalidade. Ideias, figuras e factos, Lisboa 1995; J.M. Alves Quintas, Filhos de Ramires - as origens do Integralismo Lusitano, Lisboa 2004; A. Ventura, Integralismo Lusitano. Subsídios para uma teoria política, Lisboa 2003; N. de Silva Ferreira, O pensamento integralista de Alberto de Monsaráz. Pensamento e acção, Lisboa 2005.

55 See L. Ramos Ascensão, op. cit., p. 21. In 1922, in place of Almeida Braga and Monsaraz it was Rolão Preto and Afonso Lucas that entered the Junta — see ibidem, p. 49. 
(1902-1991), and around the publisher GAMA. ${ }^{56}$ The said generation comprises, among others: publicist Fernando Amado (1899-1974); politician and diplomat Pedro Teotónio Pereira (1902-1972); historian and politician António Rodrigues Cavalheiro (1902-1984); economist José Centeno Castanho (1903-1961); historian of literature and literary critic Pedro de Moura e Sá (1908-1959); journalist and publicist Dutra Faria (1910-1978).

An especially intellectually seminal contribution into the national-Christian thought was made by the representatives of the fourth integralist generation (Quatra Geração), also referred to as "neointegralists." They launched their operations with the publication (together with the then active luminaries of the first generation) in 1950 of the manifesto bearing the title Portugal Restaurado pela Monarquia [Portugal Revived by Monarchy], and in 1957, they established the Movement of Independent Monarchists (Movimento Monárquicos Independentes). Their organ was the magazine Cidade Nova [New City]. The main representatives of this generation are: physician, historian, publicist and private advisor of the king de iure Edward III (Dom Duarte Pio), Mário Saraiva (1910-1998); journalist and essayist A fon so Botelho (1919-1998); publicist Júlio Evangelista (1927-2005); and most of all - philosopher, historian of culture, and political thinker Henrique Barrilaro Ruas (1921-2003).

The conviction of the necessity to base nationalism on the foundation provided by the Catholic doctrine about God, world, and man always accompanied the founding fathers of Lusitanian Integralism. It was Almeida Braga who already in Alma Portuguesa stressed that the very project of reviving Portugal is based upon Catholicism. While identifying the fact that the republican-democratic regime definitively severed the connection between Church and the state with the sudden precipitation of the decadence of Portugal, lasting from the epoch of enlightened absolutism, he simultaneously indicated that restoration is possible only by dint of returning to the integrity of Catholic spirit, which irrevocably marked Portugal. Very much alike, Sardinha motivated the necessity of the emerging organized nationalist actions by diagnosing the "collective spirit" of the nation; that is, that loosening the tie between the nation and religion must inevitably lead straight to the denationalization of Portuguese people. Lusitanian Integralism "rejects both the doctrine of state atheism, which is contrary to the principles of most civilized nations," and absolute "regalism with its claims to the protection of Church, being in fact a repulsive state's intervention into the realm of the spiritual. ${ }^{, 57}$ What is to be restored are the official connections with the Holy See — broken by the masonic republic. However, the newly established ties are to be founded not upon rendering Church dependent on the state, but rather on the recognition that Catholicism

56 The acronym standing for Grupo de Acção Monárquica Autónoma [The Group of Autonomous Monarchic Action].

57 Nota oficiosa da Causa Monárquica sobre o Manifiesto do Governo de 30 de Julho de 1930, [in:] L. Ramos Ascensão, op. cit., p. 122. 
is a national religion and should be therefore treated specially. The believers in other religions should be granted a relative liberty to practise them as long as the said religions do not constitute an offense to morality. ${ }^{58}$

At this point, it is worth stressing that not all integralists were Catholics before the establishment of the movement. This applies mainly to its leader, that is Sardinha, who was converted to Catholicism and later described the expediency of this conversion as his own illumination "on the road to Damascus." 59 In this context, what gains in significance is the fact that integralism assumed as its icon the symbol of a pelican ${ }^{60}$ - the bird feeding its young with the blood from its own wounded breast. The pelican has for ages not only symbolised a supreme sacrifice in a general sense in Christian iconography, but also directly referred to Jesus' sacrifice or - quite literally — to his blood.

So, one is warranted in posing the question of how it is possible that the act of re-Christianization of the nation and the state were to be carried out by nationalism, which is after all not a religious, but rather a political doctrine. The possibility of positively settling the issue was contingent upon the integralist understanding of the nationalism notion, upon its "justification" and - equally importantly - its limitations. That is why integralists from the very beginning stressed the doctrinal completeness (integrity) of the nationalist doctrine as much as the necessity of (self)limiting nationalism within its justified claims and of making it inoperative right at the threshold of what by its very nature transcends it. This thought was exceptionally clearly expressed by Pequito Rebelo, who stated that integralism may live on and thrive for the benefit of the nation only on the condition that it "transcends itself," because nationalism is the product of human design and thus, this idea — as anything man-made - is mortal. ${ }^{61}$

The ways nationalism should be "transcended", and thus limited, should be two-fold. First of all, what restraints and precludes its possible 'misbehaviours' is a deep recognition, and in consequence - a strict observance - of an authentic national tradition; in other words - conscious, and not merely impulsive or emotional, traditionalism. This view was expressed by Sardinha in the editorial Why we are coming back, which was an introductory paper to the second series of A Nação Portuguesa in 1922. "Our nationalism - he wrote therein — is not only nationalism per se but it is moderated by traditionalism, which is the acceptance of cardinal rights of the Homeland coupled with all the derivative rights on the grounds of Race and Origins." ${ }^{\prime 2}$ So, the doctrine of nationalism is here conceived

58 Ibidem.

59 See A. Sardinha, Ao Ritmo de Ampulheta. Crítica \& Doutrina, Lisboa-Porto-Combra 1925, p. 92.

60 See L. Ramos Ascensão, op. cit., p. 11.

61 [J.A.] Pequito Rebelo, Para além do Integralismo, [in:] A. Ventura, Integralismo Lusitano..., p. 91 .

62 "A Nação Portuguesa", July 1922, p. 3. It should be noted that the concept of "race" in Sardinha has, as in almost entire nationalist literature at the turn of 20th century, an anthropological- 
of as a possible or necessary means to restoring the institutions recognized as parts of authentic Portuguese tradition, which

is not only the past. First and foremost, it is the continuity of development [...] What we must then understand by the concept of Tradition is a necessity of the commonality of customs and purposes, the search for which maintains in a society some equilibrium of forces, which was actually preserved at its beginning and which allows it to persist as long as the society respects them. [...] For us, Tradition is not a sentimental mood such as a view of ruins for Romanticists or as a dead thing, the smell of which nostalgia relishes in. For us, Tradition means the persistence of continuation. Interrupting the continuity of historical legacy is the destruction of moral and social conditions, the successive links of which we should contribute ourselves. ${ }^{63}$

Traditionalist nationalism involves reviving the concept of the nation-state in contradistinction to the liberal notion of the state, with the latter being founded upon anthropological individualism, which politically translates — by virtue of universal voting - into parliamentary democracy. However, "the society consists of families, and not of individuals," 64 and "the state is not an aggregate of citizens endowed with the same knowledge and prudence; but rather it is a community of families and organized social groups." ${ }^{65}$ Reducing society to individuals, as represented by political liberalism, is rejected by integralists ${ }^{66}$ because this representation gives rise to a merely parasitic "political class," which is alienated from a society but is instead dependent upon masonry. Integralists do not want "professional politicians" - they want a "policy of crafts," that is an organic representation of organized groups, both on a political and professional basis. ${ }^{67}$ At the same time, the democratic conception of a nation is not organic because it is a contract of people and interests, and simultaneously "it is an anonymous society in which a general assembly decides in each moment about the fate of social legacy." 68 Therefore, democracy is regarded by integralists as the "destruction of any social order and the triumph of mediocracy." " As Primer stated in Monarchist, "Democracy and the Nation, Democracy and Justice, Democracy and the Army,

cultural sense, but not a biological one, as in racist doctrines. Specifically, according to Sardinha, the secret of the Portuguese history is a certain "ethnic order" shaped by Homo atlanticus, being a special pre-Aryan case of Homo europeus, being especially distinct from Homo mediterranicus - see A. Sardinha, O Valor da Raça. Introdução a Uma Campanha Nacional, Lisboa 1915, p. 154, and then M. Braga da Cruz, "O integralismo lusitano nas origens do salazarismo", Análise Social 18, 1982, no. 1, p. 156.

63 A. Sardinha, Na Feira dos Mitos — ideias e factos, Lisboa [1926], quoted after: J. Ploncard d'Assac, Doctrines du nationalisme, p. 333.

64 Idem, Ao Princípio Era o Verbo, Lisboa 1924, p. 286.

65 L. de Almeida Braga, Sob a Pendão Real, Lisboa 1942, pp. 114-115.

66 According to this contention, Lusitanian Integralism did not partake in parliamentary elections under its own umbrella; however, some integralists stood individually as candidates from the list of Catholic or regional parties.

67 A. Sardinha, Na Feira dos Mitos..., p. 30.

68 Ibidem, p. 275.

${ }^{69}$ L. de Almeida Braga, O Culto da Tradição, Combra 1916, p. 14. 
Democracy and the Authority are mutually exclusive concepts." ${ }^{, 70}$ In contradistinction to the nationalitary "national principle" — the daughter of democracy and revolution, nationalism is universalism "enlightened' by traditionalism; it is "fundamentally counter-revolutionary and Roman Catholic per se."71

Economically speaking, consequences of anti-democratism, anti-liberalism, and anti-parliamentarism also include, on the one hand, the rejection of capitalist liberalism (also referred to by integralists as economic individualism), and on the other hand - of revolutionary and socialist syndicalism, which integralism contrasted with "organic syndicalism," based upon the cooperation of classes and crafts. Integralists accused liberal capitalism of destroying economic foundations and the ancien régime (Antigo Regime), and in particular of thwarting agriculture and craftsmanship only to favour the development of one-sided industrialism. The said industrialism - "the legitimate descendant of French Revolution" - with a little help on the part of liberal governments, which were arbitrarily dissolving craft guilds, thereby destroyed the dignity of agricultural labour and of long-established crafts. Capitalism already corrupted monarchy after the top-down liberal revolution of 1834; and yet, capitalism is wholly triumphant under the republic, being — under the facade of parliamentarism — "the plutocratic state" and "bankocracy" where "money as well as international capitalist syndicates wield power." In 1922, Sardinha wrote: "What we perceived in the Republic was always the ultimate consequence of a lewd marriage of bankers and politicians, inaugurated in 1834 by the orgy of a robbery of goods belonging to Religious Orders." 72 The unconditional dominance of plutocracy leads to a new form of slavery involving transforming man into a machine. The above observation is vividly and suggestively represented by Raposo, who wrote that "[t]he Capitalist era gave rise to sad reality of Homo Faber, who now got humiliated and degraded by Dynamocracy in Homo Ferramentum [Man-Instrument - J.B.], a torso reduced to a useful instrument of Production."73 "Speculative fever," representative of capitalism, engenders the state of mind which is the "Americanization" of life, viewed from another angle as utter "paganization." "74 Furthermore, one cannot help but notice that plutocracy actually collapses into "international Jewry," aiming at the ultimate enslavement of nations. ${ }^{75}$ Due to the above,

running counter to the right to greater benefits conferred upon Plutocracy, we rather favour fair profits; against capitalist oppression, exercised by — paradoxically enough — free competition, which for ages (out of desire for profits) sheds human blood, we defend fair income, thus

70 Cartilha Monárquica, Lisboa 1916, p. 5.

71 A. Sardinha, Ao Principio..., p. 13.

72 A. Sardinha, "Estado plutocrático e parlamentarista", A Revolução 26, 1922, no. 4, quoted after: M. Braga da Cruz, O integralismo..., p. 151.

73 H. Raposo, Insurreição da Carne, Lisboa 1944, p. 39.

74 A. Sardinha, A prol do Comum. Doutrina \& História, Lisboa 1934, p. 96.

75 Ibidem, p. 48. 
liberating the mother from the factory and children from material poverty, thus restoring moral beauty of their homes. ${ }^{76}$

Integralists view "the social issue" as first and foremost "a moral issue," which reduces their duty to putting a stop to moral anarchy of capitalism and simultaneously to forestall the socialist barbarization. The economic organization of society through "organic" corporations (syndicates) - modelled around medieval guilds and crafts, but still taking into consideration new conditions of production as well as new social groups with the factory workers coming to the fore - is to restore social functions to the institution of property rights, and thus to thwart the attack of "socialist voraciousness," which "buries in darkness of its guts the light of reason, thus reducing social groups to brigandish hordes." organized in a bottom-up fashion, albeit hierarchically, at a municipal, then provincial, and finally central level, as a confederation of Technical Councils. This, coupled with the National Assembly, shall inspire the governance by the king and his ministers. Under those circumstances, the role of the state is not to stay aside, as in the doctrine of laissez faire, or to orchestrate and supplant social bodies, but rather to "aid, endorse, coordinate, adapt and especially combat and eliminate the speculations which set back national welfare. [...]. The function of the State is to protect the weak and to guide the strong." 78

The integralist project of the social reconstruction also conspicuously hierarchises classes according to the importance of the functions they respectively perform. The hierarchical structure of the "orders" consists of, in the ascending order, three parts: the people, townsfolk, and nobility. The leadership function in a society is assigned to nobility - which is an "heir of honour and desert," and for this reason nobility to a highest degree constitutes a family - rather than an individual who fails to do so. Xavier Cordeiro captures the above-stated relation in the following formula: "Family as a static element of Society. Nobility as a dynamic element of Family." 79 Due to that, gentry may serve as a role model to other classes on how to maintain and cherish family life, fulfil the duty to transfer one's legacy to one's descendants, and finally, it may be a "stimulus to moral and civil progress." $" 80$ However, the distinction must be drawn between the role of privileged village nobility - that is aristocracy, conceived of as an elite pre-destined to the participation in exercising power, and to governing provinces in particular ${ }^{81}$ — and nobility - construed as a social body ${ }^{82}$ mediating between the people and a monarch. Such a body did not have to consist exclusively of

\footnotetext{
76 Ibidem, p. 99.

77 Ibidem, pp. 95-96.

78 L. de Almeida Braga, Paixão e Graça da Terra, Lisboa 1947, p. 136.

79 A. Xavier Cordeiro, O Problema da Vinculação e o Casal de Família, Lisboa 1933, p. 20.

${ }^{80}$ H. Raposo, Insurreição..., pp. 96, 102.

81 [J.A.] Pequito Rebelo, Pela Dedução à Monarquia, Lisboa 1945, p. 33.

82 See A. Sardinha, Á Sombra dos Pórticos. Novos ensaios, Lisboa 1927, pp. 190-191.
} 
hereditary nobility; even this part thereof who do not discharge their duties and live parasitic lives may be excluded from it. Therefore, this sort of government should be construed as "the rule of the virtuous." 83

In an even more fundamental and uncompromising manner (as compared to the way traditionalism checks nationalism) nationalism is restricted by Catholic doctrine. What transcends raison d'état and calls for unconditional deference on the part of each nation is, as Pequito Rebelo wrote, "the light of truth." While directly referring to the well-known formula of French claimant Philippe, Duke of Orléans, with the above formula being adopted as a motto of the diary L'Action Française: "whatever is national is ours," and while certainly approving it, he nonetheless put things more sharply: "whatever is human is ours," and eventually "whatever is divine is ours." 84 Integralism wants a universal order, but not of any sort, but rather such that is bound with the universal concept of God. To live a "genuine life" - with respect to man and nation — is in the eyes of an integralist is "to believe," and this "to believe" is conceived of in strictly Catholic terms, that is through personal adherence to true God. ${ }^{85}$ What is necessary at this point is the distinction between true God or true religion and false religions and its idols. Bolshevism, for example, is also a religion - and a rather viable, energetic, and far-reaching one; however, its triumphs are due to the fact that it is tantamount to "the rebellion of stomachs." 86

Sardinha stressed that nationalism devoid of Christianism does not represent anything over and above "chaotic remnants of the national principle, the bastard of Democracy which balkanizes Europe, which may imminently turn into shakes of imperial exaltation." ${ }^{87}$ It is only Christian universalism that can protect nationalism from destructive and self-destructive chauvinism:

The roots of true nationalism lie in the precepts of Ten Commandments, and the durability and viability of national communities is contingent upon the degree of respecting the said commandments. Similar remarks equally well apply to universalism. In order not to divert into cosmopolitanism and to constitute a harmonious set of interests of different national groups, universalism cannot differ from the one which was advocated in the Middle Ages and which even August Comte paid a passionate tribute to. The supra-national society, restored and grounded in the only stable foundations is Christianity. ${ }^{88}$

The idea of grounding nationalism in transcendence, in the light of the Word, which "was in the beginning," should be then turned right into the imperative of incorporating Christianity into our earthly lives: "One must proceed further on and realize national goals through projecting a spirit of each Homeland into a still

\footnotetext{
${ }^{83}$ M. Braga da Cruz, op. cit., p. 161.

84 [J.A.] Pequito Rebelo, Para além..., p. 91.

85 Ibidem, p. 92.

${ }^{86}$ L. Ramos Ascensão, op. cit., p. 108.

87 A. Sardinha, Ao Princípio..., p. XVIII.

88 Ibidem, p. XVII.
} 
higher consciousness, into the highest ideal of Civilization, which is Christian Civilization, which by and in itself shaped the world as it is and which - as we firmly believe - will ultimately save it." 89 However, Christian civilization cannot countenance any additional ingredient of modern ideologies, which rather amount to a travesty of Christianity, with democracy coming to the fore in this respect. While polemicizing with Marcelino de Almeida Lima (1861-1961), who contended that democracy is nothing short of the earthly realization of Jesus' commandment "that you love one another," Sardinha pointed to a fundamental anthropological difference:

Whereas Democracy is based upon the natural good of man, the point of departure of Christianity is the original sin. And if man is good, while society is bad, then Democracy is, logically speaking, a permanent revolution. However, if man is corrupt, and society may prevent him from doing evil and punish him, then Christianity, as opposed to Democracy, constitutes an eternal cause of any legitimate order and of any legitimate government. ${ }^{90}$

Derived from the Old and New Testament and elaborated upon due to reading the works of Saint Augustine and Boethius, providentialism advocated by integralists was not a quietist sort of merely waiting for the realization of providence; instead, it attempted to inspire an active approach. The faith in possessing the religious truth revealed by God and preserved by Church teaching obligated integralists to revive the Social Kingship of Christm ${ }^{91}$ as well as to oppose "inhumane ideologies" - which, under the particular circumstances of the 20th century, implied mainly Bolshevism, this "satanic religion," as Pequito Rebelo put it. ${ }^{92}$ In the light of this commandment, integralism sketched a vision of the "apostolic calling" of Portugal, which was revived by nationalism itself and supposedly bound to enhance the glory of its history by providing Europe with a model of life under a new order. ${ }^{93}$ What it demanded from "Western reactionary maximalism" was the task of the revival of Christianity, resurrection of Christ in man, and of nations in Cristandade. ${ }^{94}$ Such an unreasonably inflated goal allows us to define integralism as a phenomenon transcending a paradigm case of a doctrine or of a purely political movement. This is exactly what Pequito Rebelo does while labelling integralism as a crusade - which is not only of national character, but also of all-human one, and its nature is not only human, but also religious. Integralism is a crusade because the former's essence is a defence of "true humanity against the barbarism of democracy and true God against satanic pride of Revolution." 95

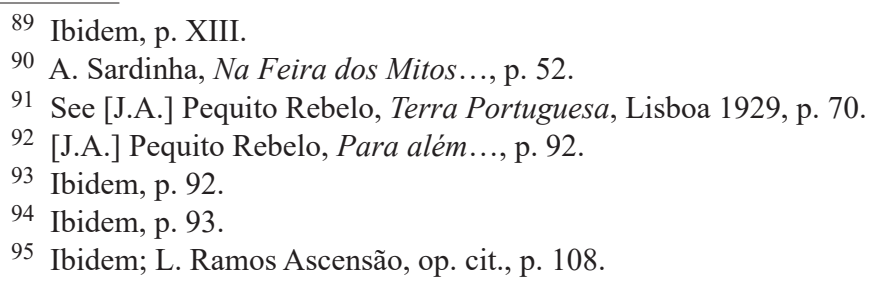


Some prominent integralists were then quite recent converts not only into Catholicism; the same applied to their views on political regimes. Sardinha himself was a republican and anarcho-syndicalist until 1912; even after a regicide in 1908, he was ostentatiously wearing a red tie. And yet, he - barely understandably - associated this fact with elitism and aristocratic manners. ${ }^{96}$ Therefore, in his case, the conversion was double and simultaneous: both into Catholicism and into monarchism. He joyfully informed Almeida Braga about it in a latter dating back to 30 December 1912, while adding that: "Monarchy and Catholicism are the only limitations that man can accept without losing his dignity or pride. [...] Monarchy, which will come, will restore peace to our poor country thanks to the reorganization of its social foundations by dint of the act of intelligence and power." " João do Amaral was an equally recent monarchist, who was back then friends with naval officer, a Carbonaro, and later the editor of a republican daily O Intransigente [Uncompromising] - Antonio Machado Santos (1875-1921). He played a crucial role in overthrowing the monarchy on 5 October 1910, while running a daring operation of seizing the barracks of the capital city garrison infantry with the forces of merely five hundred soldiers, sailors, and civilians. Another converted anarchist was Alfredo Pimenta. ${ }^{98}$

However, regardless of whether they were monarchists before or royalist "converts," integralists from the very beginning explicitly demonstrated their distinctness from what was then considered monarchist "mainstream," while proclaiming their opposition to constitutional, parliamentary, and liberal monarchy. Parliamentarism based upon individualist-liberal principle to integralists seemed to be a superfluous redundancy of the monarchy institution. By their own lights, universal suffrage is a civil war, spiritual chaos, demagogy, and the triumph of incompetence. "Almighty and omniscient" deliberating assembly is an absurd indefensible in any era, but it is especially the case in contemporary times, in which the technological specialization reached such a high level of complexity. ${ }^{99}$ For the same reasons integralists were uncompromisingly hostile to the idea of approximating the revival of monarchy via a plebiscitary method. In integralists' view, a plebiscite, putting the institution of monarchy at risk of being already ceremonially - and not only by the use of revolutionary violence - rejected by the voting people, is "the legitimization of the revolutionary law." 100 Monarchy is the choice of the ages, and that is why it cannot be a choice of the capricious will of a random collection of individuals from one generation and in one particular moment. What counts against plebiscitarism are not only principled theoretical reasons, but also practical ones. These arguments were systematically elaborated by Alfredo Pimenta:

\footnotetext{
${ }^{96}$ See M. Braga da Cruz, op. cit., p. 138.

97 Quoted after: L. Ramos Ascensão, op. cit., pp. 12-13.

98 See A. Pimenta, Nas Vésperas do Estado Novo, Porto 1937, p. 179.

99 See L. Ramos Ascensão, op. cit., p. 69.

100 A. Pimenta, op. cit., p. 160.
} 
A plebiscite is contrary to monarchic doctrine. Plebiscitary king is a king of democracy, it is a king of suffrage, a king of ballot box - i.e. a king of a party, the party that elected him. A plebiscitary king is a king of a certain opinion and a negation of the king. After all, King is not an opinion, is not a party and neither is he a group: a king is a king of nation, king of the people, an heir of whatever constituted this nation; he is the one who defended this people and who is accountable to God for transferring to his successor an intact legacy which he received. A plebiscitary monarchy is a republic.

[...] A monarchist cannot be a plebiscitarian: he must be — but not merely may be a legitimist-, which means he must be a defender of the principle of legitimacy, which, in the eyes of a monarchist, derives only from God. ${ }^{101}$

A regime-related "theorem" announced in the first manifesto of Lusitanian Integralism What we want ( $O$ que nós queremos) assumed the following form: "Organic, traditionalist and antiparliamentarian monarchy."102 It was already in the letter from 14 November 1913 that Sardinha decisively expressed his contention that constitutional monarchy collapsed because it adapted to the ideology of revolutions, which weakened and then destroyed it. That is why restored monarchy will have to be "transformed into organic, traditional Monarchy, sustaining the class balance and levelling regional differences through broadly understood decentralization, building upon its prestige on the respect for provincial spirit and for particular activities." 103

It is only Organic, traditional and antiparliamentarian Monarchy that shall save our Homeland. Decentralized monarchy, both administratively and economically speaking, is always a Monarchy which is young in its Councils and in Casa dos Vinte-e-Quatro (House of the Twenty Four ${ }^{104}$ ). However, it does have at its disposal the resources of power and flexibility which would be able to establish the endurable and stable governance sustained by the authority of the King who would care about the national interest, which would be identical with the interest of his dynasty. ${ }^{105}$

Monarchic-liberal constitutionalism discredited kingship principle because it inadvertently prepared the grounds for a republic. That is, integralism constitutes - as emphasized by Raposo - a double reaction against two feeble forms of a regime: against a parliamentarian monarchy and against "Democracy and parliamentarism, in the maze of which the Nation get lost and in which it finally

101 Ibidem, pp. 161, 163.

102 “A Nação Portuguesa” 1914, no. 1, p. 4. This formula was put forward by Luís de Almeida Braga - the writer most familiar with the works of Maurras, who in turn advocated "hereditary, traditionalist, antiparliamentarian and decentralized" monarchy.

103 Quoted after: L. Ramos Ascensão, op. cit., p. 63.

104 Casa dos Vinte-e-Quatro is a deliberative body, first of a municipal administration of Lisbon, and then in the successive cities of the kingdom and eventually in the Portuguese Empire, consisting of representatives of corporations and guilds, established 16 December 1383 by the grand master of the Order of Aviz and the Deputy and Defender of the Kingdom, prince John of Portugal (later to become king John I of Portugal), and then annulled after the victory of liberals in the civil war by virtue of a decree of 7 May 1834.

105 A. Sardinha, Na Feira dos Mitos..., p. 300. 
perishes." 106 Future monarchy will then have to "identify itself with an organized Nation." 107 As stated by Pequito Rebelo, the doctrine of Lusitanian Integralism implies "the independence of the National Interest, the justification of Monarchy and the condemnation of Democracy." 108 In an interview given on 28 August 1930 to Diário de Lisboa, and while referring to the manifesto of the government laying out the programme of the National Union and defining (by taking the words out of Salazar's mouth) the said programme as antiliberal and antidemocratic, Raposo declared that it is in line with the principles adhered to by integralists, whose creed is poles apart from monarchic liberalism, but is still insufficient due to its being silent on the question of monarchy. ${ }^{109}$ Monarchy was an indispensable and essential part of the integralist state scheme. Lusitanian Integralism is "nationalist in principle, syndicalist (corporatist) in its means and monarchist in its reasoning." 110 As

106 H. Raposo, Aula Régia, Porto 1936, p. 84.

107 Quoted after: L. Ramos Ascensão, op. cit., p. 20.

108 [J.A.] Pequito Rebelo, Para além..., p. 91.

109 See L. Ramos Ascensão, op. cit., p. 60. The monarchic issue was the main, though not the only incendiary point in the relationship between Salazar and integralists. With reference to the personal dictatorship exercised by the professor of Coimbra, they coined not only the neologism salazarquia, but also the ironic expression monarcia, which was meant as a substitute for a monarchic institution. At the same time, they fully appreciated the bitterness of all those monarchists who wanted the logical consequence of "authoritarian restoration" to be monarchic restoration. However, one should not accept the indictment appearing therein that Salazar tricked monarchists. Salazar did not deceive monarchists by giving them hope for the restoration; quite the contrary - he plainly declared that he demands from them some loyal cooperation in building Estado Novo within the existent institution, hand in hand with the republicans having joined him and without, as he put it, any arrière-pensées "romanticisms and fancies" (see A. Ferro, op. cit., pp. 22-25) therefore, we can safely say that Salazar said to monarchists: point de réveries, Messieurs! On the other hand, as far his fundamental approach goes, it was extremely pragmatic; Salazar believed that each political idea must be assessed according to its practical value and its current feasibility of being materialized. When it comes to the monarchic idea (not yet conceived of in abstract, but applied to Portugal), he assessed it as the one bereft of "dynamic force." This view he stated expressly in his first speech as a prime minister, with the speech delivered in the State Council Hall 23 October 1932 (see A. Salazar, Discursos, vol. 1, Coimbra 1961, pp. 170-171; idem, Rewolucja..., pp. 134-135). All this was additionally supplemented with his indifference towards the legitimist successors to the Portuguese throne, remaining in exile from 1834, Taking into account the fact that the last constitutional king of Portugal (Emanuel II) died childless in exile (2 July 1932) right before Salazar seized all the power (5 July 1932), the prime-minister-dictator availed himself of this fact in order to arrange him a ceremonial "national funeral" as to the last king of Portugal, while ignoring the existence of the dynastic continuity exemplified by Edward II (Dom Duarte Nuno). An even more ostentatious sign of this negligence was not inviting Dom Duarte to the board of the foundation of the House of Bragança, appointed by the government. Instead, the invitation was issued only for the mother of Dom Manuel II and to the latter's widow. However, after 1950, what was waived was the law on the banishment of princes and Salazar allowed the legitimate king to return to his Homeland; still, the latter was construed as "a private person." Summarizing, for Salazar, monarchy was an "honourable remnant," the destination of which should be a museum of national memory, and he did not see it as a viable political conception.

110 A Monarquia, 20.04.1921, quoted after: M. Braga da Cruz, op. cit., p. 144. 
Almeida Braga put it: "Monarchy is nothing else but a practical conclusion derived from Integralism itself," and "to dissociate oneself from the King is to dissociate oneself from one's Homeland." 111 Integralist nationalism must be necessarily monarchic by nature: "one cannot have genuine nationalism outside a monarchic order. [...] The integralist idea bred the monarchist idea. Monarchy is real Portuguese politics because it is in full accord with the needs of contemporary Portugal."112

Monarchy is a part of the integralist state scheme; first, as a consequence of the nationalist organization of the state itself. Then, as the crowning of the political and social hierarchization of the entire national life, founded upon family and guilds, the structure of which comprises concentric circles embracing still more and more far-reaching bodies, such as a municipality and corporation, or province as a union of municipalities and the federation of corporations. Finally, as "the political Homeland" and "the economic nation," both being unified at the highest level via a politico-legal contours of the kingdom. Therefore, the king is a pinnacle of the political and social hierarchy, at the same time being "Prince - the highest master-craftsman." 113 The order of thus conceived restoration Sardinha presented in the following fashion:

We are rebuilding society by starting to rebuild Family, which is an elementary and primary entity, in its internal monogamic and territorial regime. From Family we shift to Municipality and Corporation. From Municipality and Corporation, the aggregate of which constitutes a Province, we are moving towards Homeland, while resorting - in our actions aiming at reaching the highest goals - to coordinating functions of the State. And hence, we can find the eternal and ever-rejuvenating paths of Tradition, that is of the Order which is natural and human and without which there is no civilization or the possibility of existence. ${ }^{114}$

One should therefore agree with contemporary historian of integralism Professor Manuel Braga da Cruz (born in 1946) that the political project referred to as integralism did not imply an ordinary suggestion of restoring monarchy, but its aim was rather to overcome a liberal model of the state which proved to be destructive for the society. It was "the restoration of Portugal via Monarchy"115 that Sardinha hailed as a principled aim of integralism, which automatically implied "re-Portugization" (of Portugal itself), which clearly entails that monarchy is merely a means and not an end in itself. So, being first nationalists and traditionalists, and before they became monarchists, integralists "in the name of tradition and the nation, were combating a Republic as much as 'constitutionalist degeneration' of Monarchy itself, with the said degeneration being initiated by liberal democratism." 116

111 L. de Almeida Braga, Sob a Pendão..., pp. 44, 329.

112 Ibidem, pp. 7-8, 9-10.

113 A. Sardinha, O Valor da Raça..., p. XVII.

114 A. Sardinha, Ao Principio..., p. 292.

115 A. Sardinha, Na Feira dos Mitos..., p. 5.

116 M. Braga da Cruz, op. cit., p. 151. 
For that reason, the major demarcation line in politics, in integralists' view, was not "a regime-related issue," but rather "a political and social issue."

As far as their respective ideologies go, conservatives and traditionalists were opposed to the ideology of progressivism and they did so as defenders of the continuity of the "old order". Politically, nationalists, contesting parliamentarian democracy, desire the renewal of the political structure of the Nation. Economically, corporationists criticized capitalism for its social consequences, while searching for the method of stifling social conflicts through the limited syndicalisation of classes. ${ }^{117}$

The repudiation of liberalism, also in the monarchic form, does not imply the approval of absolutism, tyranny, statism, or totalitarianism. Integralists defended traditional monarchy while criticizing "enlightened despotism," which first infected the Lusitanian kingdom in the 18th century under the marquis of Pombal's tyranny, ${ }^{118}$ counted as the first attempt at overthrowing "our traditional constitution." 119 Absolutism, in Sardinha's view, was engendered by the illusion of extending king's power because, while destroying all the intermediate bodies and replacing the institution of a king with monarchic personalism, "absolutism put as the opposition to the State only an individual person already deprived of a thick network of local and economic associations." 120 That is why, despite the abolishment of absolute monarchy, its logical consequence - founded upon the ruins on the natural bodies of society - was statism of a centralized Napoleon-like state, one run by bureaucracy. It was already in the context of critiquing Salazarism that Almeida Braga contended that the state organized around the idea of dictatorial statism "loses a deeply humane sense, while turning into a powerful machine, ceaselessly operating and desperately accelerating. [...] Dictatorship always ends up collapsing into an abyss, which was made wide open by the madness of hostility holding between State the oppressor and Nation the oppressed."121

Dictatorship, very much like absolutism, leads to the nation being soaked by the state, thus turning the nation into a mere servant, whereas the integralist conception of state-nation assumes a converse relation between the two. ${ }^{122} \mathrm{As}$ opposed to a king, "a dictator receives only a mandate from the nation to tame intemperance of anarchy, but he lacks the moral entitlement to decree law or apply sanctions." "123 Therefore, monarchy, as Raposo submits, is the only form which allows avoiding totalitarianism, because it is does not have to resort to "polit-

117 Ibidem.

118 Sebastião José de Carvalho e Melo, 1. marquis of Pombal (1699-1782), an omnipotent, first minister under the reign of Joseph I of Portugal (1750-1777), famous for — among other things - expelling Jesuits and forcing the dissolution of this Order by the then Pope.

119 L. Ramos Ascensão, op. cit., p. 72.

120 A. Sardinha, Ao Princípio..., p. 138.

121 L. de Almeida Braga, A Revolta da Inteligência, Lisboa 1944, pp. 15-16.

122 The dispute between integralists and Salazarism revolved around the practice of Estado Novo because in theory, Salazar also advocated the primacy of the nation over the state.

${ }^{123}$ H. Raposo, Aula..., p. XV. 
ical messianism."124 The supremacy of monarchy over dictatorship can be ultimately reduced to the leadership in the former being of an institutional rather than personal nature. According to Almeida Braga, the institution of monarchy is "a body of unity and of continuity of life in the State"; the king, on the other hand, "is a symbol of eternity of one's Homeland." 125 Monarchy plays its proper role as a unity of the nation and the state, or - by the same token - of a civil society and political society. A king as "a crystal-clear mirror of the soul of the Homeland" is not an individual person but always a present family of the whole nation. "Monarchy is an organism, but not an individual. Kingship is a social force: before he became the one who enjoys rights, King became the one who incurred duties." 126 The political authority being centred around a hereditary sovereign - being specially prepared to hold this position and being endowed with a sense of responsibility stemming from their awareness of their origins and from their love towards their family, in which the king's governance shall be continued after his death - renders the king a natural defender, interpreter of the interest and the shepherd of his flock. The king guarantees order, security, and justice for all because in his conscience he is accountable to history and God while staying in awe of the latter, and at the same time his soul is filled with love towards his subjects as if they were his children. ${ }^{127}$ However, the above applies to traditional monarchy, dating back to before 18th century, and therefore to the one not corrupted first by absolutism and later on by liberal constitutionalism.

In the light of the above, it is clear to see that integralist monarchism was simultaneously fighting on two fronts: with the absolutist, statist, or totalitarian "anarchy in the top-down fashion"; and with individualistic-liberal, democratic, and patriocratic "anarchy in the bottom-up fashion." At the same time it was visible that these two political mistakes - despite the differences between them - have a common denominator, which is centralism and the hostility towards any intermediate bodies. Integralists rejected both the formula of parliamentarian monarchy ("the king is nominally in power but he does not exercise any real governance") as well as the formula of absolutism ("[t]he king wields power and he governs everything only by himself"). The motto of integralists which Sardinha derived from nineteenth-century legitimist (miguelist) José da Gama e Castro (1795-1873) was: "The king is nominally in power but he does not exercise any genuine governance." 128 Integralists put special emphasis on the fact that the idiosyncrasies of Portuguese monarchy, noticeable from its very birth and dating back to 12 th century, are its "municipal" nature. In the past, a municipal magistrate was an "indigenous element of one's Homeland," and that is why a king and

124 Ibidem, p. 87.

125 L. de Almeida Braga, Sob a Pendão..., pp. 36, 44.

126 Ibidem, p. 27.

127 See L. Ramos Ascensão, op. cit., pp. 71-72.

128 A. Sardinha, Ao Princípio..., p. 140. 
magistrates representing constituencies supplemented one another, thus striking a proper balance between authority and liberty. According to Sardinha, a wide range of liberties gained in the Middle Ages by municipalities expresses "native tendencies of [our] Race." 129 This is strictly connected with a specifically contractual genesis of Portuguese monarchy ${ }^{130}$ — certainly not in the sense of modern contractualist doctrine (Hobbes, Locke, Rousseau, etc.), which attempts to elucidate the genesis of society, the state and authority through an original contract between previously asocial individuals. Rather, the avowed contractualism is in the spirit of the medieval "pactism," which is a contract between a king and other social classes concerning their respective rights and duties. And this is the essence of the

contractual foundation of Portuguese Monarchy, which is not a sort of Monarchy based upon a German idea of possession but rather upon honourable magistracy, wherein the King is not a sovereign who is worshipped sycophantically as an idol; instead, he is simply a head of a society, and regardless of whether the society comprises the powerful or the weak, they all recognize the king's authority over them ${ }^{131}$.

In line with this tradition, Lusitanian Integralism rehabilitates municipal localism and the conception of "municipality-state"; the integralist state is the state of municipalities and corporations autonomously positing laws for themselves — or, to put it differently, municipal state and corporate state, wherein the king's authority enforces and specifies municipal and corporate liberties. ${ }^{132}$ The "monarchic principle" is therefore, by integralists' conceptual lights, a synonym of "political tradition," inseparable from "folk tradition," incarnated in "municipal liberty," which is all additionally supplemented by "religious tradition" presupposing "the Catholic unity" of the nation. ${ }^{133}$

129 A. Sardinha, O Valor da Raça ..., p. VII.

130 At this point, it should be recalled that a "foundation act" (made independent of Castile) of the Kingdom of Portugal was proclaiming infante Afonso Henriques de Borgonha a king by the first Portuguese Cortes, comprising the representatives of three classes, that is clergy, nobility, and commons, having gathered in 1143 in Lameg. The act includes - among others - the following words: "Be the King that we proclaim you, so that you should be the one according to the legitimate law, and do abide by this Law and obey it." Quoted after: A. Ribeiro Saraiva, Eu não sou um Rebelde: ou a questão de Portugal em toda a sua simplicidade, offerecida aos Políticos Imparciais e aos homens de boa fé, Lisboa 1828, http://www.arqnet.pt/portal/portugal/documentos/ars_rebelde.html. Taking into consideration the fact that the said act was recognized by Cortes of Lisbon in 1641 (that is after gaining independence yet again) as the Fundamental Law of Portugal, as "Principles of Succession to the Throne," ratified by the king John IV of Portugal via an issued patent of 9 September 1642 , allows us to validly speak of "legitimist contractualism" of the Portuguese monarchy, which derived the right to rule from an original pact between Church and classes. However, a theoretically more valid and historically more accurate, and hence not arousing confusion, expression would be "legitimist pactism."

131 A. Sardinha, O Valor da Raça..., p. XI.

132 See A. Sardinha, "Teoria do município", [in:] idem, Á Sombra ..., p. 113.

133 L. de Almeida Braga, Sob a Pendão..., pp. 13-14. 
The logical consequence of critiquing constitutional and liberal monarchy, with this sort of monarchy being still personified by Dom Manuel II, was the fact that nationalists dissociated themselves from him. Frankly speaking, integralists almost from the very beginning displayed a certain reservation towards this unfortunate monarch. It was already on 8 April 1915 when the legitimist daily A Nação published Hipolito Raposo's letter to the former minister of justice and Dom Manuel's advisor, José de Alpoim. The sender remarked that monarchism was not a personal option for integralists, but rather the affirmation of the principle of monarchic institutions' supremacy over republican ones; and that is why "at this point, the question of legitimacy is of no greater significance."134 Integralists (Sardinha, Raposo, Almeida Braga, Monsaraz, Pequito Rebelo, Cordeiro, and others) took part in the uprising of the so-called Monarchy of the North at the beginning of 1919, which was supposed to bring the throne back to Dom Manuel. The cost of that was the de-legalization of the movement as well as banishments or imprisonment. It was probably this failed effort bringing shame on the movement that was a critical test for their loyalty, since it was already in the very same year, on 19 October, that they renounced their allegiance to Dom Manuel. This was preceded by the attempts to urge him to declare that a potential restoration of monarchy shall not be equivalent to the restoration of the regime operative before 1990. It was two delegates of the Central Junta - Pequito Rebelo and Almeida Braga, who specially took a trip to London for that purpose and personally informed the constitutional ex-king about the split. ${ }^{135}$ The period in the integralist monarchism's history referred to as interregnum lasted less than a year. After negotiations with the old (miguelist) Legitimist Party were successfully concluded by virtue of the Bronnbach Agreement ${ }^{136}$ (Acordo de Bronnbach) on 2 September 1920, the Central Junta of Lusitanian Integralism formally recognized a legitimate king under the name of Edward II — Dom Duarte Nuno de Bragança (1907-1976), grandson of Miguel I and son of Miguel II of Braganza (from the second marriage). This event was preceded with the abdication of Dom Miguel II and transferring the right to the throne to his son. However, it was not a "fusion" in the proper sense because these two movements (Lusitanian Integralism and Legitimist Party) preserved their respective organizational autonomy inside a newly emergent entity bearing the name of Causa Nacional Portuguesa (Portuguese National Cause), thus giving rise to a common Conselho Superior (Supreme Council). However, it was an ideological fusion based upon national traditionalism, as explained by Raposo:

Between us and Tradition, there is indeed a common thought related to national interests, [but] we do not advocate the legitimacy of the person of a King, [we] declare the legitimacy of $n a$ -

134 Quoted after: L. Ramos Ascensão, op. cit., p. 40.

135 See ibidem, pp. 38-39.

136 The residence of Dom Miguel II in Baden-Württemberg. 
tional interest. To put it briefly, we were nationalists before we called ourselves monarchists and we remain monarchists because it is by means of Monarchy that we can serve the Nation. ${ }^{137}$

Already taking some distance, in the speech Two nationalisms dating back to 1929, Raposo mentioned the following items of the Legitimist Party's agenda: the assumption of the regional and provincial diversity as a basis for politico-administrative reconstruction of the state; a corporate organization of crafts; personal power of the king; the acceptance of the precepts of Catholic morality in the state, in the realm of education, and in families. ${ }^{138}$ The items were perfectly aligned with the principles adhered to by nationalists. Sardinha declared that Dom Miguel "represents precisely the idea which dominates in the reactionary flourishing period of the European intelligentsia," 139 and even Caetano Beirão, who was soon to change his mind, in 1919 enthusiastically noted: "We are the marching tradition, we are the Legitimism which is getting resurrected, the Nation which reacts and wants to live." ${ }^{40}$ As can be inferred from these quotes, the motives of integralists joining the heir of dynastic legitimacy was not unambiguous from the point of view of legitimism proper; hence, their position may be aptly referred to as neomiguelismo [neo-miguelism]. ${ }^{141}$

Moreover, although nationalists indeed breathed new life into dynastic legitimism, which had been in a merely vegetative state for a couple dozen years, they thereby incurred the cost involving the internal crisis of Lusitanian Integralism itself. In 1921 two prominent integralists - Alfredo Pimenta and Caetano Beirão — left the movement while establishing the pro-manuelist Acção Tradicionalista Portuguesa [Portuguese Traditionalist Action]. On 28 July of the same year, in the medium of constitutionalists, that is Correio de Manha [Morning Courier], both intellectuals as well as lawyer and essayist Alberto Ramires dos Reis, archeologist and ethnographer Luís Chaves (1888-1975), and Engineer Mateus de Oliveira Monteiro (1874-1933) - hereinafter referred to as Grupo de Cinco [Group of Five] — published a manifesto. The following figures were soon to subscribe to it: integralists Ameal and Campos, former Minister of Monarchy António Cabral (1863-1956), Alfredo de Freitas Branco (1890-1962), journalist Ernesto Gonçalves (1896-1982), artist, graphic designer, and caricaturist Joaquim Guilherme Santos Silva (1871-1948), and finally Laertes de Figueiredo. On 10 December 1921, this group started to issue a bulletin, only to be transformed one year later into a monthly Acção Realista [Royalist Action] with E. Gonçalves as its the editor-in-chief. Later the magazine in question became a daily (then edited by Ameal). Then the group also started to issue the

137 A Monarquia, 27.12.1919, quoted after: M. Braga da Cruz, op. cit., p. 143.

138 See H. Raposo, Dois Nacionalismos..., p. 12.

139 A. Sardinha, Na Feira dos Mitos..., p. 139.

140 This declaration was cited by integralists, thus rubbing it in, after its author seceded from the movement, in A Monarquia, 6.06.1921, quoted after: M. Braga da Cruz, op. cit., p. 149.

141 This expression is used by prof. Braga da Cruz - see idem, op. cit., p. 149. 
weekly A Voz Nacional [National Voice], with the editor-in-chief being L. Chaves. On 8 December 1923, the movement changed its name into Acção Realista Portuguesa [Portuguese Royalist Action]. The insuperable paradox of this circle was an apparent contradiction of promoting (following the footsteps of integralists) the agenda of organic, traditional, and antiparliamentarian as well as anti-liberal monarchy, while simultaneously adhering to Dom Manuel, who was after all an incarnation of a liberal sort of monarchy. ${ }^{142}$

However, an even more painful blow, which called into question the expected benefits of the covenant with legitimists, was delivered to integralists by the king's hand. On 17 April 1922, a representative of Dom Manuel, Aires de Ornelas, and a representative of Dom Miguel II as well as of the infanta Maria Aldegundes, signed a pact in Paris between the two dynasties. Both sides were acting on behalf of then underage Dom Duarte Nuno - duke of Almada e Avranches ${ }^{143}$ (1897-1978). There was animosity between the dynasty which continued since the War of Two Brothers. ${ }^{144}$ The pact has become known as Pacto de Paris [the Pact of Paris]. The first — and at the same time most important — provision was the postponement of resolving the issue of the future monarch's identity. This issue was to be decided at the discretion of the Cortes Gerais of the Portuguese Nation after restoring monarchy. Till then, however, all the monarchists were supposed to faithfully unite under the banner of Emanuel II, with it being "the banner of Homeland and the one which will save Portugal." 145 The second provision ceded to the Cortes the decision on what the "Political Constitution of the Restored Monarchy" was to be; whereas the third provision conferred on them a right to solve "the religious issue"; however, only "in line" with the Holy See.

All these provisions ran counter to both the principles of legitimism and to the political ideário [ideology] of Lusitanian Integralism. ${ }^{146}$ Although its two envoys (Monsaraz and Almeida Braga) participated in these negotiations as Dona Aldegunda's advisors and accepted them, the Central Junta dissociated itself from

142 After all, after his death, ARP recognized "Miguelist" Dom Duarte Nuno, but only as a successor of childless Dom Manuel, and not as its father or grandfather.

143 Strictly speaking: Lourenço de Jesus Maria José Vaz de Almada, 5. conde de Almada e 17. conde de Avranches.

144 As a matter of fact, in the dynastic-formal aspect, the Pact of Paris was a repetition or a continuation of The Pact of Dover, entered into by Dom Manuel II and Dom Miguel II ten years earlier (30.01.1912), wherein Dom Miguel - in exchange for the promise on the part of Dom Manuel to waive the law on the banishment of the miguelist lineage of 1838 - recognized the rights to the throne of an constitutional ex-king, with the rights in question being transferrable to Dom Miguel's son only in case Dom Manuel failed to have his own descendant. And so, Miguel II in fact "traded" his own legitimacy, to which he obviously did not have a right — see A. Cabral, El-Rei D. Duarte II, Lisboa 1934, chapter 3. "O Pacto de Dover e o Pacto de Paris", pp. 65-88; L. de Magalhães, A Crise Monárquica. Documentos para a História e Liquidação de Responsabilidades, Porto 1934.

145 O Pacto de Paris, [in:] L. Ramos Ascensão, op. cit., pp. 110-111.

146 L. Ramos Ascensão labels this document as a "masterpiece of diluted Machiavellianism" — see idem, op. cit., p. 46. 
them ${ }^{147}$ and disowned the pact in its full extent. As outraged Raposo explained, the said pact was not to be accepted because "it puts the Parliament above the divine law as far the religious issue goes, above the King's law as far dynastic issues go, and above the laws of the Nation as far as a constitution is concerned." 148 The official stand was taken by the Central Junta in its declaration dating back to 4 May 1922.

1. Asserting the fact that in the agreement, the principles of the Portuguese Monarchy were not safeguarded, [Junta] regrets to inform that it painfully recognizes the moral and political inability to perform its [agreement's] provisions, thus proclaiming henceforth its [Junta's] independence.

2. Since Lusitanian Integralism cannot incur responsibility for delaying or forestalling the advent of monarchy, it forthwith suspends its operations as a political organization till the moment in which the circumstances aptly demonstrate that it is only methods and doctrines of Nationalism that may feasibly ensure the restoration.

3. Reaffirming as its goal the continuing of combating the republic through the defence and the doctrinal promotion of the principles of Lusitanian Integralism - however, not in the field of political actions, and till the new conditions thereof have been established which would proclaim the Monarchy of Municipalities and Corporations, in which the Cortes Gerais shall introduce - in line with the law - a Legitimate King, we recognize as such the Person of His Royal Highness, His Majesty Edward Nuno Braganza. ${ }^{149}$

However, the price to pay for the loyalty to one's ideário was - following the second point of the declaration - giving up the ambitious intention for integralism to shift into a political action, only to retreat into a meta-political realm again, with the latter being only supplemented with the activity in the social realm in municipal, parochial, and education-related structures. In consequence, this also meant marginalising integralism even in the monarchist camp, with it being actually in toto cast out of official political life. This uncompromising attitude is accounted for by L. Ramos Ascensão with the fact that integralism was a doctrinal movement, rather than the one inclined towards activism. It was also elitist in nature and incapable of mobilizing masses: "integralist leaders, aristocrats of reasoning and of a unique kind of moral elegance could not ingratiate with the crowd and neither could they lure them. The former might be politicians (but does it always hold true?); and yet, they were constitutionally unable to be demagogues." 150 For a very short time, towards the end of 1925 (which is already after the death of the leader and main theoretician of the movement, Antonio Sardinha), some hope appeared to reverse this unfavourable trend due to the fact that in November of the said year, infanta Guimarães (on behalf of her nephew) terminated the Pact of Paris, which was applauded by integralists. On 12 March 1926, the

147 They were also excluded from the Central Junta.

148 A Monarquia, 26.10.1923, quoted after: M. Braga da Cruz, op. cit., p. 144.

149 “A Attitude da Junta Central do Integralismo Lusitano perante o Pacto de Paris", [in:]

L. Ramos Ascensão, op. cit., pp. 112-113.

150 L. Ramos Ascensão, op. cit., p. 47. 
Central Junta - while remarking that two infelicitous delegates to Paris showed full solidarity with the standpoint taken by the leadership, to which they were also brought back (and so the composition thereof was the following: Raposo, Almeida Braga, Monsaraz, Pequito Rebelo, Preto, and Lucas) - made another declaration. Junta, while recalling that integralism had never really accepted this agreement, rejoiced at the fact that the king's guardian recognized it as void and invalid and congratulated her on listening attentively to all sound reasons provided by all those loyal subjects of Edward II who could not come to terms with the concluded compromise. Integralists also paid homage to the Supreme Council of the Legitimist Party for the fact that being "loyal to the tradition of its honourable political patrimony, it had never sworn allegiance to the provisions of this pact." Thus confirming their unwavering loyalty to the principles of integralism and to the dynastic laws of "Prince Royal of Portugal, His Highness Edward Nuno," integralists announced the return to political activity, simultaneously urging all the monarchists to intensely fight against the Republic and calling for "restoring Portugal by the real Monarchy as soon as possible - the representative Monarchy of municipalities and corporations." $" 151$

This promise to return to the political scene, however, did not materialize for a reason which was impossible to anticipate. Two and a half months later, on 28 May 1926, an army commanded by hero of the combat against Germans in Mozambique, General Manuel Gomes de Costa (1863-1929), inspired by the success of the May rebellion in Poland having taken place just two weeks earlier, launched a military coup. As opposed to all the previous ones, it put a definitive end to nominally parliamentarian governance and to what the president of the Republic in the period of 1911-1915, Professor Manuel de Arriaga (1840-1917), labelled as "cursed political turmoil." Generals and colonels, however, had neither a specific political programme except for the desire to restore order, nor — apart from a moderate nationalist standpoint - strong ideological beliefs. However, they flatly rejected one element, which was precisely the restoration of monarchy. Moreover, they decided not to continue parliamentary government, since it was to this very sort of regime that they attributed the main cause of political upheavals in the country. After all, this situation, marked by ideological-political indeterminacy on the one hand and a negative attitude towards parliamentarism (and hence to political parties as well) on the other, proved conducive to the process of eroding the existent formations. This included Lusitanian Integralism, although this very formation was, as we know, not a party but rather a "doctrinal movement." Therefore, almost from the very beginning of military dictatorship, political "fugitives" started abandoning integralism, planning to endow military government with some ideological features - although these were not necessarily identical.

151 O Regresso da Junta Central do Integralismo Lusitano à actividade politica, [in:] L. Ramos Ascensão, op. cit., pp. 115-117. 
Those who first joined the dictatorship while disowning integralism (headed by Rolão Preto) simultaneously moved to the side of fascism and were dreaming of a "national revolution" - permanent, frenetic, politically and socially radical. By contrast, these integralists who originated mainly from "the second generation" (amongst whom the one to attain the highest rank was Marcello Caetano) and who decisively made accession only when power shifted from the military hands into the hands of an ascetic civilian and professor of economics, wanted something entirely different. They sought a peaceful, moderate, paternalist, and socially conservative counterrevolution, albeit parting with "romantic dreams" of their older friends about the restoration of monarchy. At the same time, when this second programme assumed a specific shape of an authoritarian regime, albeit of a still uncompromisingly republican nature, of the New State with a dictatorial "presidentialism of a prime minister" system, the proponents of the first programme beat a retreat, thus repudiating dictatorship or even making a two-time effort to overthrow it and to run a nationalist-syndicalist revolution. Still, both the first and the second programme implied tearing apart integralist ideário of the "organic, traditional and antiparliamentarian monarchy," "the monarchy of municipalities and corporations," and - since 1920 - also the legitimist one. Under these circumstances, the situation of integralists loyal to their ideário became catastrophic. In fact, it became "catacomb integralism," which was tolerated only with respect to its cultural activity till the end of World War II (which forced certain "democratization" of the system, not to become ostracised by the victorious Western democracies headed by the USA themselves). However, once it attempted to go beyond the said cultural activity, it was repressed. ${ }^{152}$

A genuinely tragicomic epilogue to the attempts at restoring monarchy and the relationship between the dictator and monarchists was written by a small, albeit consisting of prominent figures, monarchist fraction within the elite among the authorities of Estado Novo. Its comprised, among others: former minister of justice and personal friend of Salazar from his student years, Professor Mário de Figueiredo (1890-1969), former minister of finance, Professor J oão Lumbrales (1905-1975), and former minister of internal affairs Augusto Cancela de Abreu (1895-1965). Professing the need for "doing away with a temporary mandate of the Chief of State," they made an attempt at introducing the issue of restoration into the project of revising the Constitution, with the project filed by the government after the death of the long-time president Marshall Carmona (18 April 1951). He always loyally stood in the shadow of the prime minister-dictator, whom he could - at least theoretically — dismiss at any moment. While debating over the project in the National Assembly, Figueiredo all of a sudden declared what follows: "There has come a time to decide whether we should continue with the Republic or restore Monarchy," thus having gained an applause from the group

152 The climax of these repressions was exiling (in 1940) H. Raposo to Azores. 
of his political friends. However, then the chair of the Assembly, Albino dos Reis (1888-1983), shouted in their direction: "You are madmen! Restoring monarchy now? I can't make heads or tails of it!" 153 and the debate was thus concluded.

The history of the two nationalist formations in Portugal scrutinized herein the Nationalist Party headed by Jacinto Cândido, and Lusitanian Integralism - illustrates a series of interesting parallels as well as oppositions between them.

First of all, although the times of their respective operations were different - however not very distant - by studying their respective histories one may get the impression that they had operated in entirely different countries. There is no continuity between them, nor are there any organization-personal "overlaps" or any references (save the already quoted commendatory mention of the Nationalist Party in Raposo's speech). This is rather surprising considering the fact that Portugal is a fairly small country whose political and intellectual life was centred around only as many as four cities (Lisbon, Coimbra, Porto, and Braga), which makes it rather difficult for people representing similar beliefs to fail to notice or encounter one another.

Secondly, although the primary ideological trademark of both movement was nationalism, they were both solidly founded upon Christianity (Catholicism), which helps distinguish them from a series of other nationalisms - not excluding the nationalism that served as an inspiration to the former two, that is French nationalism, having a positivist and agnostic foundation, albeit seeking a common ground with Church as a stronghold of the order. A slight difference seems to be made, however, by the fact that whereas the formation headed by Cândido alluded almost exclusively to contemporary Catholic social teachings — with the programme of a social reform being so pronounced in the encyclical Rerum novarum by Leo XIII - integralists broadly adopted the Catholic classical theological-philosophical corpus, that is the one of patristics and medieval scholastics.

And finally - which is of utmost importance to us considering the research perspective assumed herein, focused on analysing the relations between nationalism and monarchism - we can witness here an exceptionally interesting similarity. It is the case that in this respect, two circles went exactly opposite ways. The first formation, founded still during the times of constitutional monarchy (and, as it turned out, at the time of its decline, which certainly could not be known ante factum by its founding fathers), started from monarchism as a sui generis obviousness, declaring the desire to strengthen and revive the slightly impaired

153 Quoted after: J.M. Quintas, Os monárquicos e as eleiçóes presidenciais de 1958, http:// reynodeportugal.blogspot.com/2011/04/os-monarquicos-e-as-eleicoes.html. 
authority of the king. This, however, during its operations, was met with scepticism on the part of the authorities, used to a bipartisan system with two liberal parties alternately exercising power. On the other hand, when monarchy was overthrown, Cândido - still politically lonely back then - started to distance himself more and more from the attempts to restore it, while recognizing that thus decayed tree will not bear fruits any longer; so, nationalism should henceforth exclusively protect the national interest and hold on to defending religion and the rights of the Church. Eventually, Cândido ostentatiously dissociated himself from monarchists after their failed uprising in 1919. At the same time, Lusitanian Integralism was founded by people who - only partly, but this applied to Sardinha, who was its leader - at the very end of monarchy and even at the beginning of the republic, despised monarchy and were enthusiastic republicans and anarchists. However, they experienced real illumination, simultaneously converting into monarchism and Catholicism. This, in turn, marked their monarchism with a shade of passionate exultation and a search of (in history, philosophy, as well as in theology) content capable of filling and reanimating the monarchic form. They were tired of liberal constitutionalism and parliamentarism and aimed to reach the formula of organic, traditional, and antiparliamentarian monarchy. So, while comparing the approaches of both nationalisms to the issue of monarchy, we might safely say that Cândido's monarchism was (as long as it lasted) inherited and exclusively practical. And when monarchy - the actually existing one - failed and collapsed, it was rejected as an unnecessary prop. Integralist monarchism, however, was acquired, theoretical, and intellectual, even mystical and... poetic. Therefore, it was immune to any practical failures. What is not without significance, then, is both the sociological aspect of the mentioned nationalisms and the psychology of their respective founding fathers. Cândido originated from the establishment of nineteenth-century liberal monarchy and boasted considerable political experience - even as a minister. Sardinha was a symbolist poet, originating from the decadent climate of fin-de-siècle, and an aesthetising anarchist who unexpectedly found himself on his road to Damascus and turned out to be an enlightened apostle of Christian monarchy.

\section{References}

Abúndio da Silva M., Nacionalismo e Acção Católica, Porto 1909.

Almeida Braga L. de, A Revolta da Inteligência, Lisboa 1944.

Almeida Braga L. de, O Culto da Tradição, Combra 1916.

Almeida Braga L. de, Paixão e Graça da Terra, Lisboa 1947.

Almeida Braga L. de, Posição de António Sardinha, Lisboa 1943.

Almeida Braga L. de, Sob a Pendão Real, GAMA, Lisboa 1942.

Almeida J. de, Nacionalismo e Estado Novo, Lisboa 1932.

Alves Quintas J.M., Filhos de Ramires - as origens do Integralismo Lusitano, Nova Ática, Lisboa 2004. 
Ameal J., Panorama do Nacionalismo português, Lisboa 1932.

Archer de Carvalho P., Nação e Nacionalismo - Mitemas do Integralismo Lusitano, Coimbra 1993. Avelino de Jesus Q., Nacionalismo Português, Porto 1932.

Barreiros Malheiro da Silva A., Miguelismo. Ideologia e mito, Minerva, Coimbra 1993.

Barrilaro Ruas H., "O Integralismo como doutrina política”, [in:] idem, A Liberdade e o Rei, Lisboa 1971, pp. 191-206.

Barros M.N., Bernardo L., Cunha J.A., A Filosofia política no Integralismo Lusitano, Lisboa 1987.

Bartyzel J., "Nowe Państwo Antónia Salazara na tle nacjonalizmu chrześcijańskiego w XX-wiecznej Portugalii”, [in:] Autorytaryzmy iberyjskie - Hiszpania Franco i Portugalia Salazara, eds. B. Szklarski i M. Słęcki, Warszawa 2010, pp. 97-118.

Bartyzel J., "Nacjonalizm a monarchizm: przypadek portugalski”, [in:] idem, Prawica - nacjonalizm - monarchizm. Studia politologiczno-historyczne, Radzymin-Warszawa 2016, pp. 155-220.

Bartyzel J., "Nacjonalizm chrześcijański w Portugalii", [in:] Nacjonalizm a konserwatyzm i monarchizm. Action Française i jej promieniowanie / Le nationalisme face au conservatisme et au monarchisme. Action française et son rayonnement, eds. J. Bartyzel, D. Góra-Szopiński, Toruń 2011, pp. 249-268.

Braga da Cruz M., “O integralismo lusitano nas origens do salazarismo”, Análise Social 18, 1982, no. 1.

Cabral A., El-Rei D. Duarte II, Lisboa 1934.

Campos F., A Genealogia do pensamento nacionalista, Lisboa 1931.

Cândido [da Silva] J., A Doutrina Nacionalista, Porto 1909.

Cândido [da Silva] J., As medidas de salvação pública, nas sessões da Câmara dos Deputados de 13 e 17 de Janeiro de 1892, Lisboa 1892.

Cândido [da Silva] J., Autobiografia, ed. J.L. Dias, Castelo Branco 1962.

Cândido [da Silva] J., Memórias intimas para o Meu Filho (1898-1925), ed. J.L. Dias, Castelo Branco 1963.

Cândido [da Silva] J., Resposta a El-Rei, discurso nas sessões de 23, 27 e 28 de Novembro de 1906, Lisboa 1907.

Cândido [da Silva] J., Vida Velha e Vida Nova. Discurso proferido na sessão de 18 de Abril de 1902, Lisboa 1902.

Cartilha Monárquica, Lisboa 1916.

Carvalho da Silva A., O Partido Nacionalista no contexto do Nacionalismo Católico (1901-1910), Lisboa 1996.

Casa Nova Martins M., "Congressos do Partido Nacionalista”, Alameda digital 1, 2006, no. 2.

Cordeiro Gonçalves E.C., Católicos e Política (1890-1910) - O Pensamento e Acção do Conde de Samodães, Maia 2004.

Cordeiro Lopes A., O pensamento e a acção de João Ameal - Um percurso antimoderno, entre o Integralismo e o Salazarizmo (1917-1934), Lisboa 1995.

Ferrão C., O Integralismo e a República. Autópsia de Um Mito, Lisboa 1964-1965.

Ferro A., Dyktator wspótczesnej Portugalii: Salazar, trans. E. Boyé, Warszawa 1936.

Lousada M.A., "El miguelismo o la contrarrevolución en Portugal", [in:] Identidad y nacionalismo en la España contamporánea; el Carlismo, 1833-1875, ed. S.G. Payne, Madrid 1996, pp. 181-194.

Lousada M.A., "Nacionalismo e Contrarevolução em Portugal. O episódio Miguelista (1823-1834)", Luso-Brazilian Review 29, 1992, no. 1.

Magalhães L. de, A Crise Monárquica. Documentos para a História e Liquidação de Responsabilidades, Porto 1934.

Medina J., Salazar e os Fascistos. Salazarismo e Nacional-Sindicalismo a história dum conflicto 1932-1935, Lisboa 1978.

Mónica M.T., Errâncias Miguelistas (1834-43), Lisboa 1997.

Múrias M., Tres Gerações e o seu destino, Lisboa 1941.

Neto V., "O nacionalismo católico em Jacinto Cândido", Revista de História das Ideias 22, 2001. 
Olaio N., "Jacinto Cândido da Silva (1857-1926): o nacionalismo católico através das memórias de um dos seus fundadores", Lusitania sacra 16, 2004, series 2a.

Pequito Rebelo [J.A.], Pela Dedução à Monarquia, Lisboa 1945.

Pequito Rebelo [J.A.], Terra Portuguesa, Lisboa 1929.

Pereira P.T., Nacionalismo português, Coimbra 1967.

Pimenta A., Nas Vésperas do Estado Novo, Porto 1937.

Ploncard d'Assac J., Doctrines du nationalisme, Vouillé 1978.

Proença R., Acerca do Integralismo Lusitano, Lisboa 1964.

Programa Nacionalista, Tipografia Peninsular de Monteiro \& Gonçalves, Porto 1903.

Quintas J.M., Os monárquicos e as eleiçóes presidenciais de 1958, http://reynodeportugal.blogspot. com/2011/04/os-monarquicos-e-as-eleicoes.html.

Ramos Ascensão L., O Integralismo Lusitano, Porto 1943.

Raposo H., Aula Régia, Porto 1936.

Raposo H., Dois Nacionalismos: l'Action Française e o Integralismo Lusitano, Lisboa 1929.

Raposo H., Insurreição da Carne, Lisboa 1944.

Ribeiro Saraiva A., Eu não sou um Rebelde: ou a questão de Portugal em toda a sua simplicidade, offerecida aos Políticos Imparciais e aos homens de boa fé, Lisboa 1828.

Salazar [de Oliveira] A., Discursos, vol. 1, Coimbra 1961.

Salazar [de Oliveira] A., Rewolucja pokojowa, trans. Z. Grabski, Warszawa 1939.

Saraiva M., "Integralismo Lusitano e sua Actualidade", [in:] idem, Frontalidade. Ideias, figuras e factos, Lisboa 1995.

Sardinha A., A prol do Comum. Doutrina \& História, Lisboa 1934.

Sardinha A., Á Sombra dos Pórticos. Novos ensaios, Lisboa 1927.

Sardinha A., Ao Princípio Era o Verbo, Lisboa 1924.

Sardinha A., Ao Ritmo de Ampulheta. Crítica \& Doutrina, Lisboa-Porto-Combra 1925.

Sardinha A., Na Feira dos Mitos — ideias e factos, Lisboa [1926].

Sardinha A., O Valor da Raça. Introdução a Uma Campanha Nacional, Lisboa 1915.

Silva Ferreira N. de, O pensamento integralista de Alberto de Monsaráz. Pensamento e acção, Lisboa 2005.

Ventura A., Integralismo Lusitano. Subsídios para uma teoria política, Lisboa 2003.

Vide F. da, O Pensamento Integralista. Seus fundamentos histórico-scientificos, determinação e oportunidade do seu objectivo social e politico, Lisboa 1923.

Wielomski A., "Faszyści portugalscy wobec dyktatury Antonio de Oliveiry Salazara", [in:] idem, Faszyzmy tacińskie. Sen o rewolucji innej niż w Rosji i w Niemczech, Warszawa [2011].

Xavier Cordeiro A., O Problema da Vinculação e o Casal de Família, Lisboa 1933. 